\title{
Lake Qooqa as a Narrative: Finding Meanings in Social Memory (A Narrative Inquiry)
}

\author{
Assefa Tefera Dibaba
}

Citation: Dibaba, Assefa Tefera. 2021. Lake Qooqa as a Narrative: Finding Meanings in Social Memory $(A$ Narrative Inquiry). Humanities 10: 77. https://doi.org/10.3390/h10020077

Received: 25 February 2021

Accepted: 24 April 2021

Published: 18 May 2021

Publisher's Note: MDPI stays neutral with regard to jurisdictional claims in published maps and institutional affiliations.

Copyright: (C) 2021 by the author. Licensee MDPI, Basel, Switzerland. This article is an open access article distributed under the terms and conditions of the Creative Commons Attribution (CC BY) license (https:/ / creativecommons.org/licenses/by/ $4.0 /)$.
Department of Oromo Language, Literature, and Folklore, College of Humanities, Language Studies, Journalism, and Communication, Addis Ababa University, Addis Ababa 1176, Ethiopia; asafadibaba@gmail.com

\begin{abstract}
Lake Qooqa in Oromia/Ethiopia started out as a man-made lake back in the 1960s, formed by the damming of the Awash River and other rivers for a practical function, i.e., for hydroelectric power. The lake flooded over the surrounding picturesque landscape, shattered sacred sites and the livelihoods of the Siiba Oromo, and damaged the ecosystem in the area, which was later resuscitated to have an aesthetic function for tourists. Available sources showed that people used the lake for irrigation, washing, fishing, and drinking, while tanneries, flower farms, and manufacturing facilities for soap and plastic products were set up along the banks without enough environmental impact assessment and virtually with no regulations on how to get rid of their effluents, which contained dangerous chemicals such as arsenic, mercury, chromium, lead, and cadmium, giving the lake a blue and green color locally called bulee; hence, the name the "Green Lake". In the present study, following a string of "narrative turns" in other disciplinary fields of humanities and social sciences (folklore, history, and anthropology), I use social memory and life hi/story narratives from Amudde, Arsi, Oromia/Ethiopia, to consider a few methodological and theoretical questions of folkloric and ecological nature in doing a narrative study: What is social memory? What does social memory reveal about the people and the environment in which they live? Is a personal narrative story folklore? Where do stories come from? What should the researcher do with the stories s/he collected? Hence, this study aims to tackle two objectives: first, using social memory data as a means to connect social identity and historical memory set in a social context in which people shape their group identity and debate conflicting views of the past, I explore the Green Lake as a narrative, which is, in its current situation, a prototypical image of degradation and anthropogenic impacts, and trace trajectories and meanings of social memory about the shared past, i.e., the historical grief of loss that people in the study area carry in their memory pool. Second, toward this end, I use people's stories from the research site, particularly Amina's story about the loss of seven members of her family from complications related to drinking the polluted water, as evidence to show, sharing Sandra Dolby Stahl's claim, that the narrative of personal experience belongs in folklore studies to the established genre of the family story.
\end{abstract}

Keywords: social memory; narrative inquiry; personal narrative; life hi/story; folklore; family story; ethnoecology/ecotheology; Lake Qooqa; Oromo/Oromia; Ethiopia

bishaaniifi haati xuurii malee xurii hin qaban.
there is nothing dirt about water and mother but guilt (when gone).

Oromo proverb. Amudde

\section{Introduction}

The purpose of the present study is to explore contested social memory narratives about the unsettled human-ecology relationship in Amudde, using "narrative" methods of "temporality", "sociality", and "place" (Connelly and Clandinin 1990). People's narrated life experience directs attention toward the past, present, and future (temporality) of places, events, and things in the area of study (place), which affects the personal and 
social conditions of the participants understood in terms of cultural, institutional, social, and linguistic narratives. A narrative approach "is closely linked to life history, because it involves telling stories, recounting-accounting for-how individuals make sense of events and actions in their lives with themselves as the agents of their lives" (McAlpine 2016).

In the present study, following a string of "narrative turns" in other fields of folkloric/literary studies, ethnoecology, environmental history, and anthropology, I use "social memory" and "life hi/story narratives" from Amudde, Arsi, Oromia/Ethiopia, to trigger a few rather broad methodological and theoretical questions of a folkloric and ecological nature: What is a social memory narrative? What does a social memory reveal about the people and the environment in which they live? Is a personal narrative story folklore? Where do stories come from? What should the researcher do with the stories s/he collected?

Thus, focusing on the Amudde people's narrative of the Qooqa Lake and using social memory data from the area, this research project deals with issues of the politics of resources and trajectories of lives and local knowledge/poetics about social-ecological systems in the study area. Among the myriad of other cycles of chaos and renewals in social-ecological systems and problems facing Oromia and its people to date, the political paralysis, economic inequality, and cultural cultural and social injustices, while inseparably interlinked, exacerbated the "wicked problem", namely, the social-ecological crises (for example, the case of the Qooqa Lake), which largely stems, as will be discussed shortly, from the denial of agency and humanity to the vast poor and resilient struggling segments of the society. While African ruling elites, for the most part, are the major players and surrogates of Western-led environmental and economic policies, this elemental human and ecological dimension has not received sufficient academic attention yet.

By linking the two dimensions of the stated problem, in this project, using the social memory and narrative inquiry method, I gathered evidence from across interdisciplinary fields of ecological humanities, folklore, and social sciences and from the social memory of people in Amudde in January, March, and April 2020 through interviews and observations to determine,

(a) how local institutions, ecological knowledge, and indigenous practices work with the mainstream environmental conservation strategies to enhance cultural resilience and what strategies are socially and culturally acceptable;

(b) what conflicting views and contested narratives are carried in the people's social memory;

(c) what scientific conservation plans and local water harvesting methods are used; and

(d) what strategies the people use to recount the humanitarian and ecological crisis in the area and to envision the prospect of ethnoecological approach to solve the problem.

\subsection{Background}

When social capital is weakened, diversity is disregarded, and the local people are not consulted in decision making about their lives and the environment in which they live, governance is dysfunctional and resentment and fierce resistance become obvious (Krasny and Tidball 2015). Currently, the Oromo are in some debate about what constitutes the human good when things fall apart and how to endure life in adverse conditions as the socio-political and ecological crisis is unfolding in Ethiopia.

\subsubsection{The Oromo People and Oromia}

The Oromo are the most populous single ethno-nation in Northeast Africa, and they constitute the larger portion of the inhabitants of Ethiopia (Central Statistical Agency CSA). They speak Afaan Oromoo (Oromo Language), a Cushitic branch, which is spoken in Ethiopia and Kenya and is the fourth most widely spoken language in Africa after Arabic, Swahili, and Hausa (Lodhi 1993). Until they were colonized by Abyssinia, another African nation, with the help of the European colonial powers of the day, in the last quarter of the nineteenth century (1870-1900), the Oromo developed their own socio-political and cultural system called the Gadaa system, a uniquely democratic institution of paramount 
human and ecological significance (Luling 1965; Harris 1884; Hassen 1992). To find out how the local ecological knowledge and local institutions address the major challenges of eco-colonialism (Cox and Elmqvist 1997) in Oromia, which has imposed immense human dislocation, environmental degradation, violations of land property rights (land grab) and equity, and compensational injustices, the life histories of the people are a reliable source (Hassen 1992; Jalata 2012; Jackson 2002; Gedicks 1993). The case of the historical forceful eviction of Siiba, the Jiille branch of Tulama Oromo, in the previous Qooqa plain, is no exception. In this study, the life experience narratives of informants and social memory from Amudde, East Arsi, Oromia, and Amina's story in particular, are to be analyzed from the people's perspective. In so doing, the end goal of this research, in the long-run, is to seek out ways in the local culture to support the involvement/empowerment of the public through their active participation in community decision making about social-ecological services (sound human-environment relationships) and to work on better cultural ecology practices in the face of rapid socio-economic changes and ecological dynamism (Sheridan 2008).

\subsubsection{The Research Setting}

The environmental resources in Finfinne, the capital (Addis Ababa), and in its localities are threatened by severe pollution due to population growth, unplanned urbanization and less or no attention given to developing an ecocity, inconsiderate human (anthropogenic) activities, and incongruous industrial effluents and dry wastes that contaminate river waters (Qabbana River, the two Aqaqi Rivers, and Mojo River, among other tributaries of Hawas River) and lakes (Qooqa Lake and others) southeast of the capital (Kottak 1999). Since its foundation in 1887 by removing the Oromo natives of Galan, Yekka, and Gullalle of the Torban Oboo lineages, Finfinne (Addis Ababa) has grown from sparse settlements to an expansive and highly populated city to date, causing waterbodies and ecosystems southeast of its vicinity to suffer immeasurable crises. Its recent unplanned urban development and industrialization has caused considerable internal displacements and environmental degradation and, consequently, the encroachment has been met by furious protests over the last few years.

\section{Lake Qooqa}

The Aqaqi-Qooqa wetlands (Figure 1) are part of the Awash River catchment, about 30 miles southeast of Finfinne/Addis Ababa, the capital. The Qooqa reservoir catchment area is $1495 \mathrm{~km}^{2}$, and originally it had an area of $12,068 \mathrm{~km}^{2}$, but the catchment has suffered much erosion resulting in sediments in the reservoir (Ferezer Eshetu 2012). The fringe of the marsh has some tall sedge, grasses, and reeds, while the rest of the area is a farmland and grassland with a few scattered trees, mostly figs (Degefu et al. 2011a, 2011b). Studies show that the Qooqa Reservoir and other shallow water bodies are "of high ecological and socioeconomic importance", and this importance has been "compromised by nutrient enrichment that resulted in turbid, algae-dominated waters associated with animal communities ... the changes to aqua-system that lead to loss of biodiversity and pose a serious threat to public health" (Yeshiemebet 2016, citing Perrow et al. 1999). 


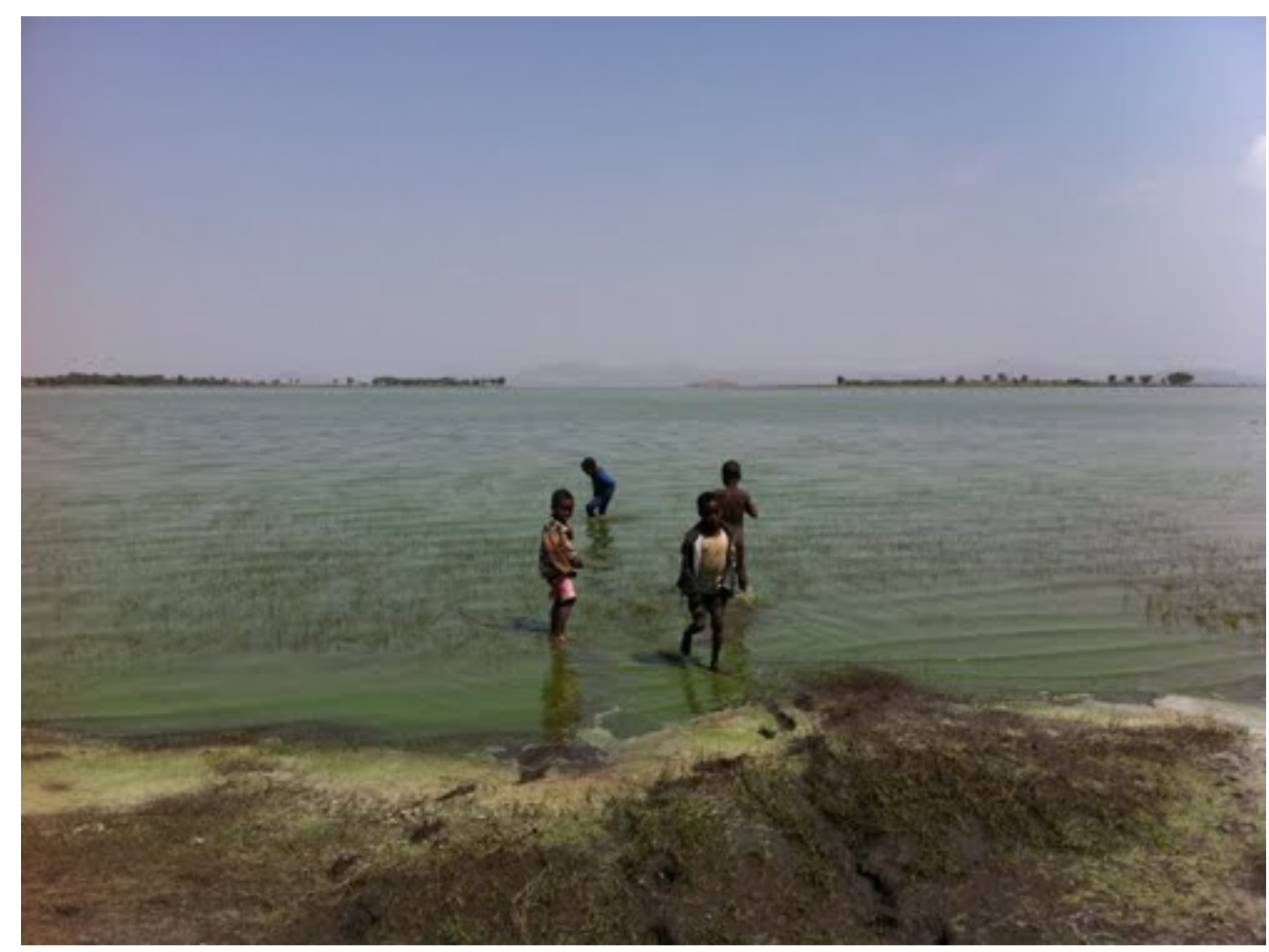

Figure 1. Qooqa Lake, southeast of Finfinne. Courtesy of Geoview.info.

The Mojo River is another tributary of the Awash River with its own two tributaries, the Wadecha and Balbala. The river is also vital for numerous bird species. Birdlife International identified the Aqaaqi-Qooqa wetlands as a crucial staging ground for winter migratory bird species. According to laboratory analyses of toxic industrial chemicals in the river waters, and by available clinical data from people in the watershed, there is evidence that the Mojo River is one of the two most polluted rivers in Ethiopia. The rivers feed into the Qooqa Lake with their contamitants and wastes out of Finfinne, the capital.

\section{The Pollution Problem}

Ethiopia is considered the water tower of east Africa because of its great resource of surface and groundwater. However, in spite of its available water, the country is unable to provide access to clean water in either rural or urban areas. With the growth of unplanned urbanization and industrialization in the capital, Finfinee (Addis Ababa), humanity faces many "wicked problems". Rural water pollution is one grave danger that necessitates a long-lasting solution and action. According to the World Health Organization (WHO), 3.58 million people die every year from water-related diseases. In the Oromia Region, the under age five mortality rate is 193 per 1000 .

In central Oromia, around the Qooqa Lake, Mojo River, and the Aqaqi River, pollution has been putting tremendous pressure on both social and natural capital. This includes solid and liquid wastes recklessly dumped in the rivers and streams. Solid wastes are not recycled. Studies show that the practice of recycling solid wastes such as composting and biomass is at its experimental stage in the country (Ademe and Alemayehu 2014). The liquid waste management is also at its rudimental stage, and there is no binding rule implemented for industries regarding how to dispose of their wastes without affecting the environment and the society (Yeshiemebet 2016).

According to available data, the crucial environmental problems within and around the capital are caused by human (anthropogenic) factors and poor industrial waste disposals, which include the following: car washing, garages, petrol stations, chemical factories, paint factories, tanneries, slaughterhouses, market centers, breweries, textile factories, 
hospitals, tire factories, thread and garment factories, oil mills, flour mills, steel factories, tobacco factories, and pharmaceutical factories. Furthermore, most houses (residential or business) have no connection to the municipal sewer line; the majority of industries are located in the capital, industries are established close to rivers and discharge wastes into the waterways, and the people have no awareness of sustainable waste management or education about waste reduction, recycling, composting, or energy generation. The majority of industries were planted without practical environmental enforcement before delivery of the land.

The major wastewaters that drain industrial disposals into the Qooqa reservoir include the Aqaqi River (great and little Aqaqi), the tributary of Awash River, Mojo River, which in turn takes the raw effluent directly from the Mojo mill factory and from the butter houses and poultry farms, and the Shoa and Ethio-tanneries, which discharge their effluent into Lake Qooqa (Yeshiemebet 2016; Fasil Degefu et al. 2013). Social memory narratives and personal experience stories about the social-ecological crisis caused by industrial wastes discharged into the rivers and lakes, particularly the Qooqa Lake, will be collected to determine the people's resilient reintegration process (Norris et al. 2008).

\subsection{Purpose}

Research into the meanings of social memory and narratives that come from folkloric and ecocultural data about Lake Qooqa and other humanitarian and ecological crises in the area is thin on the ground. By applying folkloric, historical, and ethnoecological methods, the present study is hoped to have the potential to advance the frontier of knowledge in the field of social memory research by introducing interdisciplinary approaches to the "wicked problem", namely, a recurring ecological crisis in Amudde, and in so doing, it lays a fertile ground for further research into indigenous practices used to balance human and ecological solidarity at risk. As part of the impact activities, in collaboration with local institutions, custodians, and environmental education workers, a narrative-based ecological study can engage individuals and families in awareness raising tasks and empower the community to become more resilient and restore healthy ecosystems (Mowo et al. 2011). Witnessing the interdisciplinary understanding of "oral history", Della Pollock (2005) writes in Remembering, "the performance of oral history is itself a transformational process. At the very least, it translates subjectively remembered events into embodied memory acts, moving memory into re-membering" (p. 2). Thus, the lasting impact of the present study is hoped to be that local institutional custodians and environmental (education) agents will work jointly and act together to challenge the top-down policies that violate human rights to live in a safe environment and disregard the local institutions and community's role in decision-making processes from the ground up (Ruiz-Mallén et al. 2012).

\subsection{Objectives}

Using the social memory and narrative inquiry method, the objective of this interdisciplinary research is to explore the politics of resources in the study area, to identify strategies used to recount the historical humanitarian and environmental crisis, to consider the parameters and limits of the cultural resilience of the people, and, in so doing, to envision a reconstructive and transformative outlook on social-ecological issues in Amudde. Thus, the basic assumption here is that the social memory narrative is informative about the historical grief of loss and the local ethnoecological knowledge that are understudied in Amudde and its surroundings, and it plays a significant role in sustaining indigenous social-ecological practices and informing policies.

Toward that end, the present study looks forward to a youth- and women-focused social-ecological skill learning (eco-literacy) based on the local ecological practices and environmental education to maintain a healthy human-nature nexus and to enhance ecocultural resilience (Rappaport 1971). I collected relevant data through interviews and observation in Amudde to analyze using cultural, folkloric, and historical trend analyses. Examining closely the belief system of the people was helpful to find out the underlying 
values of the culture, uncertainties, fears, ambitions, taboos, and morals that constitute an ethical human-nature nexus. Studies show that the performances of rituals, personal life histories, festivals, and coronation of sacred trees/sites have considerable effects on environmental attitudes and can play a major role in revitalizing the ecological practices changed over time (Gumo et al. 2012; Ingold 2003).

\subsection{Rationale}

My interest in the present research and collecting available relevant documents about the Qooqa-Lake-related human and environmental crisis in Amudde started five years ago, when I was attending "Civic Ecology" courses at Cornell University, NY, after my PhD in Folklore and Anthropology from Indiana University, Bloomington, USA. It was at that time that I encountered the Al Jazeera BBC Documentary titled "People and Power/The Price of Development", based on Amina's narrative from Amudde, Arsi, about the tragic death of seven members of her family due to the Qooqa Lake water-pollution-related complications. Two major reasons make the current study compelling: first, the magnitude of human and environmental damages that people in the study area have suffered over the last sixty years, and second, the lack of studies conducted with significant paid attention to the problem from the people's perspective using the social memory method and the people's life experience narratives by focusing on indigenous ecological practices in the area.

\subsection{Organization of the Study}

This paper is organized into five sections. The first section deals with the objectives, purpose, and background of the study and a brief history of the Oromo people. In the second section, a review of literature on the social memory and narrative method and religious and socio-cultural pressures that led to the erosion of local knowledge and contamination of the lake is presented. Section three discusses discourses on the social memory method, followed by section four, where I interpretatively explore empirical examples of social memory narratives built around Lake Qooqa: its use, perceptions about the use, i.e., subjective perceptions of the reality (reality as witnessed) and their objective representations (reality as objectively practiced and described), and implications of the use as recounted by the people in Amudde (reflexivity) through interviews, group discussions, and observations of reality as agreed upon (intersubjective dimension). Social memory, personal stories, and their narrative repertoires are reconstructed, analyzed, and relocated by means of the contextualization of the stories within the broader metanarrative of Oromo (macro-)history. Section five concludes that beyond the knowledge to be obtained from a modest contribution made by the present research into meanings of social memory, from related future research into ecological crisis and indigenous practices from the people's perspective/s, it is hoped, some societally important and positive outcomes can be anticipated.

\section{Theorizing the Social Memory Narrative}

In the present project, it is not my plan to provide a definitive account of advances into narrative inquiry. Rather, I shall trace some of those terrains in the inquiry landscape along which the "social memory narrative" method has moved, focusing on those trajectories that have cut across the field of folklore (and narrative) research. Thus, for this purpose, I shall take up issues specific to the ecological crisis with specific reference to Lake Qooqa and its surroundings to address the uses and purposes of narrative inquiry in ethnoecology. Thus, some of the theoretical and methodological questions to consider here include: What is a social memory narrative? What does the story reveal about the people and the environment in which they live? Is a personal narrative story folklore? Where do stories come from? What should the narrative researcher do with the stories s/he collected? 


\subsection{Some Conceptual Considerations}

Building on the research of other scholars, next, I emphasize the importance of understanding social memory as contextually and culturally based and capturing what people mean when (or even why) they say "nan yaadadha", that is, "I remember", or "nan hirraanfadhe", which means "I forgot". The purpose of this research is, using a folkloric "social memory" and "narrative inquiry" approach, to explore the uncharted terrain of Qooqa Lake, one of the "water bodies in the Oromian/Ethiopian Rift Valley subjected to escalating environmental degradation due to the increasing industrial and agricultural activities" (Yeshiemebet 2016). What is narrative? For the purpose of the present study, by "narrative" I mean, sharing Margaret S. Barrett's view (Barrett and Stauffer 2006), a "mode of knowing" and "constructing meaning", a "method of inquiry", or a "story, an account to self and others of people, places, and events, and the relationships that hold between these elements ... the capacity to speak, and through that medium, to construct a version of events" (pp. 6-7).

\subsubsection{Discourses on Social Memory}

What is social memory? Social memory as a concept is used to explore the connection between social identity and historical memory, and seeks to answer the reason why members of a social group think they belong to the group and share a common past. To put emphasis on the internalization of "group identity", some scholars use "collective" memory, while some prefer "social" memory to pay attention to a "social context" in which people shape their group identities and decide to agree, disagree, or negotiate their conflicting views of the past and search for common memories to meet present needs. To Fentress and Wickham (1992), "memory is a complex process, not a simple mental act", and it is used to describe various acts, such as to recognize, to remember, to recall, to recount, and to commemorate, which shows that "'memory' can include anything from a highly private and spontaneous, possibly wordless, mental sensation to a formalized public ceremony" (x). It is "individuals who do the remembering"; so, what is "social" about this individual act, i.e., "memory"? Fentress and Wickham rightly argue that "the essential answer is that much memory is attached to membership of social groups of one kind or another" (ibid). From a folkloric perspective, Ben-Amos and Weissberg (1999) succinctly state that "cultural memory" is the creative invention of the past to serve/critique the present and to envision the future, and they explore the dynamics of "cultural memory" on the level of everyday life contexts and show how memory is shaped and how it operates in uniting society on some common ground.

Of the relationship between "collective memory" and "historical memory", Maria Todorova writes, the former "represents lived experience, and the second is concerned with the preservation of lived experience, i.e., 'between one's sense of having an experience, and an external representation of that experience'" (Todorova 2004, p. 4). Hence, as Bernbeck et al. (2017) convincingly argue, "anything in and from the past can be studied as part of a process that relates past and present-a diachronic relationship", and sharing Halbwachs's view they add that "memory" and "history" are distinct as "in the realm of memory the present is the dominant side, while historical disciplines give the past the primary place" (Bernbeck et al. 2017, p. 13). To stress this temporal dimension of memory against history, Bernbeck claims, "we have set memory apart from history because of its firm placement in the present" (Bernbeck et al. 2017, p. 24).

What is forgetting? If memories express the connectedness of minds to bodies and bodies to the social and natural world around them, then this connectedness and "continuity is also the source of normal forgetfulness as well" (Fentress and Wickham 1992, ibid. 39). The act of forgetting can be explained simply by "how a story, in passing from generation to generation, is successively altered", particularly in oral societies, to describe the oral transmission of expressive cultures, as there is "no basis for comparison" of the version told by the storyteller as the version learned many years ago (Fentress and Wickham 1992, ibid. 40). The transmission of memory poses a problem regarding the distinction between 
"remembrance of the common past as made available through conversation, narration, songs, gestures (religious, cult, dance), pictures, emotions and empathy (performance), and of specific accounts of the past told by memory specialist who address a specific privileged audience" (p. 34). Plato claims (in his seventh letter) that "writing weakens the individual memory"; likewise, Ulrike Sommer (2017) maintains, "memory specialists preserved epic cycles, religious lore and genealogy, such as the Greek and Irish bards, or the Griots in Western Africa" (p. 34). Even though there can be "a tendency to overrate the time-span that shared memory can survive", and chances for forgetting over a long period of time, there are longer oral transmissions claimed among oral cultures, as among the Borana Oromo (Oba-Smidt 2016), reaching back several years, "which is impossible to prove and rather unlikely" (Sommer 2017, p. 34). Despite the time limit to remembering past events, among the different types of knowledge about the past include "personal memory, which has a very limited temporal reach; and intergenerationally transmitted narratives and histories" (Sommer 2017, p. 37).

What is "narrative inquiry"? In this study, narrative inquiry is understood as an interpretive approach that involves a storytelling method. Thus, the story becomes an object of study about how the individual (or group) makes sense of events and actions in their lives set in place and time. The study aims to explore the potential of narrative inquiry as a research tool in ethnoecology (folklore-orianted ecology) to enhance the understanding of how stories convey local knowledge about the unbalanced human-nature nexus (Lee and Newfont 2017), and how narratives enable sense-making and identity construction.

What should the narrative researcher do with the stories s/he collected? Ethnographically speaking, "the first-person accounts are realistic descriptions of events" set in time, and thus "it is the events described and not the stories created that are the object of investigation", whereas, in using narrative inquiry as a multidisciplinary research tool, "narrative analysis then takes the story itself as the object of study" (Mitchell and Egudo 2003, p. 2). In this regard, in doing a narrative study, the bewilderment about "interpretation" and "analysis" is not simple to disregard. Some might consider "analysis" to imply objectivity, and "interpretation" to imply subjectivity, whereas "both work in tandem because we analyze narrative data in order to develop an understanding of the meanings our participants give to themselves" (Kim 2016, p. 189). That is, through analysis of thematic structure and of social and cultural referents, narrative researchers interpret meanings, which "are to be analyzed and interpreted concurrently in a transitional period to the research text" (ibid. 2016, p. 190). To Ruthellen Josselson, "narrative research is always interpretive at every stage ... from conceptualization of research, to data collection, to writing research text" (Josselson 2006, p. 4).

Is a personal narrative story folklore? The multifaceted narrative form is another challenge to a narrative researcher. One can connect "social memory" and "narrative" in Margarete Sandelowski (1991) note quoting Roland Barthes: "Narratives assume many forms. They are heard, seen and read; they are told, performed, painted, sculpted and written. They are international, trans-historical and transcultural: 'simply there, like life itself'" (Sandelowski 1991, p. 162). In a non-folkloric context, Sandelowski considers spoken narratives as emphasizing (a) textual matters, that is, the syntactic and semantic devices connecting parts of the text; (b) ideational matters, the referential meaning of what is said; and (c) interpersonal matters, or the role of relationships between teller and listener as reflected in speech (Sandelowski 1991, p. 163).

Elliott Oring (1986), an American folklorist, shares the view that "narrative is another word for story, and narrating is a method by which an experience is transformed into a verbal account", recapitulating an experience and "matching a verbal sequence of statements to some sequence of events which is purported to have occurred" (ibid). "Among some sub-varieties of "narrative" are: origin myth, Saint's legend, memorate, fabulat, novella, aetiological tale, magic tale, joke, jest, animal tale, catch tale, clock tale, formula tale, personal experience story, and life history (emphasis mine), just to name a few" (Oring 1986, p. 121). 
To Oring, "personal experience story" and "life history" make a sub-variety of a spoken "narrative", and whether those are folklore is left to us to bet.

However, from what Oring claims, what makes a "narrative" a "folk narrative" depends on our conceptualization of what "folklore" is. That is to say, to Elliott Oring, "folk narratives are generally conceptualized to be those narratives which articulate primarily in oral tradition and are communicated face-to-face" (pp. 122-23). Thus, from what has been stated, it is to be understood that "oral tradition" as a "culture bearer", "language" as a "medium", and a "face-to-face communication" as a "social context" are among other characteristic features that a "personal experience story" and a "life history" have to share with a "folk narrative", since the two modes of communication (a "personal experience story" and a "life history") exhibit "oral" rather than "written" channels. However, I should add here that some characteristics of "folk narratives" include the following: folk narratives must be re-created with each telling; with this recreation processes, they reflect, like social memory, the past (language, symbols, events, and forms) to evoke meaning at present about contemporary situations, concerns, values, and attitudes; renovation, that is, the past is made to speak the present, reflecting both the individual and the community; the narrator re-creates in accordance with his/her own disposition and circumstances (Oring 1986, ibid., p. 123).

This is an attempt to theorize social memory narrative data analysis and interpretation, which involves the broad concepts of stories, narratives, and storytelling using "stories as an approach to research inquiry; narrative analysis as a way of crystallizing arguments and assumptions; and storytelling as a way of understanding, communicating, and influencing others" (Kim 2016, p. 189). Among the various perspectives of doing narrative research, one can consider descriptive and explanatory methods. According to Margarete Sandelowski (1991), in descriptive narrative research, the focus of the researcher is to describe:

(a) individual and group narratives of life stories or particular life episodes;

(b) the conditions under which one storyline, or emplotment and signification of events, prevails over, coheres with, or conflicts with other storylines;

(c) the relationship between individual stories and the available cultural stock of stories; and

(d) the function that certain life episodes serve in individuals' emplotment of their lives" (Sandelowski 1991, p. 163).

In this study, narratives are understood as stories, an ordering of events in time and place, "an effort to make something out of those events: to render, or to signify, the experience of persons-in-flux in a personally and culturally coherent, plausible manner ... elements of the past, present, and future at a liminal place and fleeting moment in time" (Sandelowski 1991, p. 162). To repeat Sandelowski, narrative analysis is an act of finding a "narrative meaning", used to "reveal the discontinuities between story and experience and focus on discourse: on the tellings themselves and the devices individuals use to make meaning in stories" (Sandelowski 1991, p. 162).

\subsubsection{Revisiting Ethnoecology/Ecotheology}

People are connected by their stories about their lived experiences and stand united or divided by their truths. One way to understand a hold that stories and songs can have on us is by examining closely the various ways culture can channel those resentments and express resilience (Dibaba 2018). The stories people tell each other, the song they sing, and prayers they chant reflect and shape their deepest feelings. The question people pose to officials, for example, "if this is your land, where are your stories?", which came to be the title of Edward Chamberlin's superb book, is an insight and glimpse into the deep-seated resentment about land and land resources are usurped by the government in the name of common good, bringing a new sense of urgency to find a common ground (Chamberlin 2003). Resentment of ecological injustices knows no borders. The bitter words of the late Ken Saro-Wiwa are about the "deadly ecological war" of eco-colonialism waged by the Anglo/Dutch Shell Oil Company since 1958 against the Ogoni micro-minorities in Nigeria. Like Oromia in 
Ethiopia, the Ogoniland is a "breadbasket", a major food producing area; the Rivers State, Nigeria, and the Ogoni are resentful of resource exploitation, as they are victims of an environmental crisis caused by oil spills and blowouts.

The oppressed communities often have to deal with a particular set of vulnerabilities. To help in the search for actual causal mechanisms or resilience processes, it is pertinent to identify vulnerability factors, which include economic, social, environmental, and psychological risks (Vasseur and Jones 2015). The available literature identifies two kinds of risk factors that have a significant effect on the social-ecological resilience of the Oromo around the capital and those in the watershed of the Aqaqi and Mojo Rivers, southeast of the capital: the socio-political risks (adversities), or the historical grief, and the environmental risks, the water contaminants and solid wastes being one typical problem, among others. After the ecological crisis (Hufford 1995), one set of risk factors involves the historical loss or trauma about the unresolved historical grief of loss the Oromo suffer in general. That is, the unresolved historical grief and trauma is the loss that the Oromo communities of Galan, Gullalle, and Ekka suffered and still suffer from the time of the Abyssinian war of conquest (Sahlasillassie, king of Shoa, r.1813-1847; Minilik II, r. 1889-1913) and the Subba of Jille clan near Amudde.

\subsection{Oromo Ethnoecology/Ecotheology}

Ethnoecology is a human and nature-focused approach to the local ecological knowledge about people's relationship to their environment (Johnson 2010; Berkes 1999), and ecotheology is a concern about a sanctified relationship between God and humankind, God and nature, and humankind and nature (Kelbessa 2010). Ethnoecologically speaking, to Leslie Main Johnson (2010), land, for example, is not limited to meaning soil or the surface of the Earth. Instead "land" encompasses the totality of beings existing in the place that a people live. It is a homeland, and includes the earth itself and its landforms-the waters, the sky and weather, the living beings, both plant and animal, spirit entities, history, and the will of the Creator. Land in this sense cannot be measured in hectares or reduced to a value of dollars, though the land provides both livelihood and identity. Land constitutes place, rather than space (Casey [1996] 2010, p. 3).

Similarly, from an Oromo perspective, the community "have user and management rights but lack judicial rights to dispose land" (Kelbessa 2010). Among the Oromo, there is a general trend that "human beings originated from this land and returned to it" (Kelbessa 2010, p. 71) (cf. the narrative, Uume Walaabuu baate/Creation began at Walaabu). He adds that the Oromo also "share the view held by many Africans", and that is, "for Africans, land belongs to all, living and dead. We will live in this land where our fore-parents lived and where our great-great-grand children will live. To make sure that all benefit from this wealth, we have to take care of it properly now. This value system cuts across all ethnic groups in Africa" (Kelbessa 2010).

Unlike Garrett Hardin (1968) "tragedy of the commons", a theory that holds that common property regimes lead to land degradation as each individual user focuses on maximizing their own gain at the expense of that of the community, the African, hence, the Oromo common property management system, and its ecological resilience has various religious and ecological attributes. Workineh Kalbessa, in his Oromo "ecotheology" studies, refutes the governmental and non-governmental claims that peasant farmers in Ethiopia are the major causes of environmental disasters "because of their obvious lack of knowledge about the processes of degradation and about the means used by outsiders to intervene positively"; rather, Workineh rightly argues that the "traditional land tenure system had been one of the major causes of environmental degradation, economic inequality, and exploitation of peasant farmers by the landlords in Ethiopia" (Kelbessa 2010, p. 52).

The African ethnoecological/ecotheological view of traditional environmental conservation includes "taboos", "totemism", and "common property" (Mawere 2013, pp. 6-13) to manage the environment and to survive adverse conditions. Thus, the Oromo local knowledge upholds abdaarii (dakkii) or qoolloo (sacred groves/trees) such as "hoomii, 
qilxuu, hambaabeessa, waddeessa and others which are well protected by some peasant farmers", and Workineh Kelbessa affirms,

"in autumn, every year, ... in most cases women used to sit under qoolloo trees and pray to Waaqa (God) for rain, for protection from sickness and death, famine, snow, drought, and failure of crops, for gifts of longevity, children, prosperity, peace and for protection from evil spirits and wild animals. The Oromo are not worshipping the material symbols, but the spirits of the symbols represented by trees". (Kelbessa 2010, p. 75)

\section{Social Memory Narrative Method}

The main sources of the present study are different available relevant documents, interviews with key informants selected by a purposeful sampling method, and community elders and ritual leaders whom I contacted through a snowball technique in the study area and personal observations. I used interdisciplinary approaches such as "narrative trends" / "story-telling", "ecopoetics" / "ethnoecology", and "environmental history" visà-vis the Oromo worldview, an Oromo "ecotheology" perspective. I have also surveyed relevant studies and publications on social memory narratives and indigenous knowledge and practices.

\subsection{Methods and Research Questions}

The inquiries below indicate the complementary character of the two knowledge systems, namely, local knowledge and modern science, and the urgent need to promote collaborative projects between researchers and the local population to balance the humannature relationship.

\subsubsection{Research Questions}

Using a "social memory narrative inquiry" method, the present study makes an attempt to answer the following questions. In the people's social memory narrative: what are the major causes of Qooqa Lake water pollution and other related challenges from the people's perspective? What are the conflicting views and contested narratives in the people's social memory? What local knowledge is worth attending to in order to eco-culturally and historically alleviate the social-ecological crisis in the people's lived experience (resilience)? What local institutions are available for decision making and how are they environmentally sound and economically viable to alleviate the crisis locally? Finally, what strategies do the people use to recount the humanitarian and ecological crisis in the area and to envision the prospect of an ethnoecological approach to solving the problem?

\subsubsection{Methods}

To answer the research questions, I collected primary data from the research area through observation, case-study, and interview tools based on fieldworks in the local ecological culture. There are personal and collective memory narratives used as preliminary evidence to show that, as the poor waste management system in the capital (Addis Ababa) continues, humans and non-humans living in the fringes of the city and southeast around the Aqaqi River, Mojo River, and Qooka reservoir continue to suffer incalculable disaster. I also used the "life history" approach, which plays an important role in redressing the wrongs suffered by the people.

\subsection{Interviews and Focus Group Discussion}

In the interview, I asked the informants (individuals and group) to reflect on Oromo cultural ecology, on what is sacred and secular in their domain, on indigenous ecological practices handed down through collective memory, on their water harvesting personal experiences, on alter/native ways of balancing human-ecology solidarity, on the causes and consequences of the Qooqa crisis, and on the challenges to and limitations of indigenous 
ecological practices. Throughout the interview process, I obtained not only information (facts, names, and dates) from the interviewees, but also insights, thoughts, attitudes, beliefs, and practices relevant to the lake and other related issues. The study also involved focus group discussions in which five participants (four males and one female) discussed different aspects of the Qooqa crisis.

\section{Interview Project and Discussion}

In this section, the data collected on multiple narrative voices (multivocality) and nuanced senses of place (multilocality) about Lake Qooqa will be presented and discussed. This section is organized into two subsections.

First, contested worldviews:

(a) Although it is generally agreed that the culture and tradition in which both Christianity and Islam emerged were Jewish and Arabic cultures, respectively, it remains unclear how both religious creeds could totally fit into the diverse cultures of the world in general and to the culture of the study area in particular.

(b) It is equally puzzling how the (eco-)culture of the study area can accommodate non-indigenous religion (e.g., Islam, Christianity) without being marginalized itself. Second, contested ecologies and the "bulee" / "algae" metaphor

(a) It is to be discussed that by taking advantage of the lack of regulations and clear policies, state-owned facilities such as the Qooqa dam and the power plant, multinational corporations (e.g., floricultures), factories (e.g., tanneries), and local entrepreneurs (e.g., horticultural irrigation systems) unsettled the ecosystem, nullified the traditional ecological knowledge and culture, dislocated the local political system and integrity of the indigenous people (social cohesion), with immeasurable psychological impacts and incompensable loss of values.

(b) Metaphorically speaking, the Oromo and other peoples around the capital, Finfinne (Addis Ababa), have been subjected as citizens as they suffer forced evictions and a wide range of injustices. Findings from available sources show that

(1) the majority of dumping sites are in Oromia, concentrated around towns, riverbanks, and grazing lands (e.g, the controversial Sandafa landfill), and industrial plants are located by the rivers and lake-sides with their effluents (locally called bulee) discharged into waterbodies. As a result of those randomly selected dumping sites and poor waste management systems, people suffer a prevalence of diarrhea, body allergy, cough, and other diseases (e.g., pneumonia and sinus).

These issues of environmental and human problems remain grave concerns for people in the study area following the building of the Qooqaa dam in 1960, the encroachment of factories, the expansion of floriculture, and the introduction of non-indigenous religious creeds resulting into a multiplicity of voices (multivocality) and nuanced senses of place (multilocality).

\subsection{Social Memory and Personal Experience Narratives}

The folkloric element of storying resentment in the narrative voice of informants from Amudde, Doddota District, East Arsi, and the descriptions of injustices depict the dystopia of the top-down policies and development plans that disregard the involvement of the local population. Bruce Bradshaw argues that narratives or deeper traditions and stories explain the world and shape perspectives, actions, and behavior of members of the communities and work as a background to everything visible in the culture (Bradshaw 2002, p. 240). Hence, social memory narratives carry the values and beliefs of the society and direct the daily life of the people, and it is fair to say that real changes will occur when the people take command of their narratives and transform their social-ecological system. 


\subsection{Five Interviews}

As will be presented next, the data in this chapter confirm that the different factors that compel changes in the study area include different world-views and ideologies, dominant religious creed/s, varied and competing political systems, and top-down policies that often disregard the ground-up development strategies and internal dynamics of community decision making. A few cultural sites in the study area, the Jaanoo Muudaa Mountain near Balaale and Haroo Roobii near Amudde, among others, which are now totally abandoned because of both religious (Islamic) and development-induced (politico-economic) pressures upon the residents, and Lake Qooqa, have been emphasized in the interviews and group discussions.

To begin with, I asked my informants to recount the major causes of Lake Qooqa water pollution and other challenges from their perspective, what conflicting views and contested narratives they know of about the human and ecological catastrophe, what local knowledge is worth attending to to alleviate the social-ecological crisis from their lived experience and to make sound decisions about what affects their lives and the environment in which they live, what local strategies are used to recount the politics of resources, and what is to be done to envision better humanitarian and ecological situations.

My informants unanimously agreed that, traditionally, there were secret societies and sacred sites (mountains, well-springs, lakes, and sacred groves and trees) where people gathered to worship Waaqa (God) for rain, peace, abundance, and fertility and to make decisions about what affects their life and the environment in which they live. To date, those places have been abandoned, and local institutions are weakened mostly by externally induced factors, which are religious, sociocultural, and political (Lee and Newfont 2017).

\subsubsection{Interview 1: Narrating Jaanoo Muudaa}

(a) What local knowledge is worth attending to in order to eco-culturally and historically alleviate the social-ecological crisis in the area, from your experience, and to make sound decisions?

Among other sacred sites in the study area where local secret societies used to meet for a pilgrimage is Mountain Jaanoo, which is located south of Balaale in Doddota District. It is characterized by degraded forests and fragments of volcanic eruption, which occurred several years ago, and its ash flows and ash falls are seen covering all the down-slope areas. The ritual site of the muudaa was at the foot of Mount Jaanoo, where seekkara ritual songs and dance performance were carried out until the practice was gradually banned, according to Ahmad Gammada Butta (75) of Balaale, following the influence of Islam in the area.

According to my informant, Ahmad Gammada of Balaale (Figure 2), the people of Doddota, Adama (Saapho Dabbullee), Hexosa, and many other neighboring districts in East Arsi make a pilgrimage in December to Jaanoo Muudaa to pray, worship Waaqa (God) together, sing songs, and perform ritual dances at the sacred site demarcated for the same purpose at the foot of Mount Jaanoo (Figure 3). 


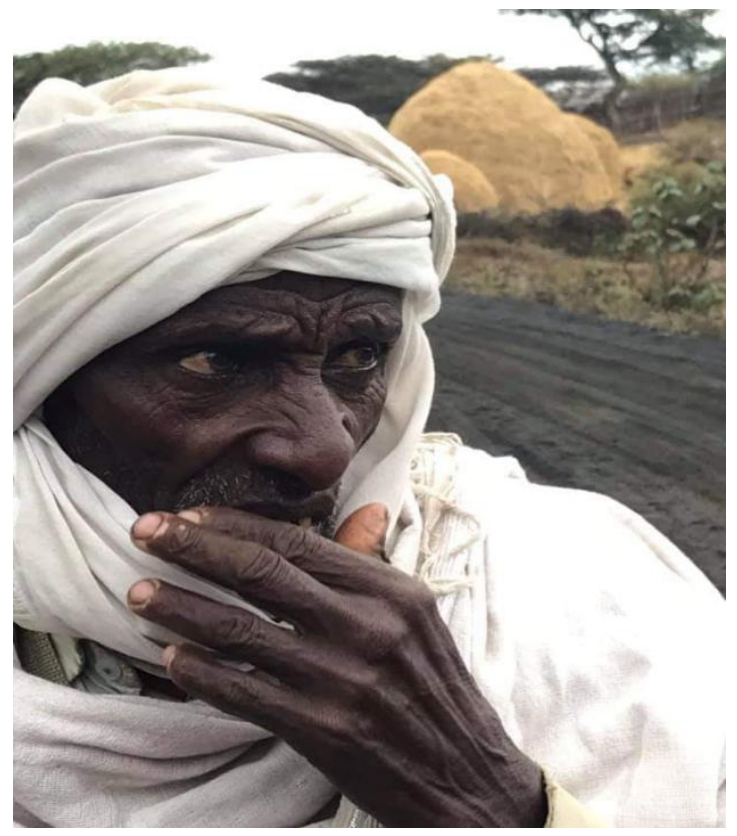

Figure 2. Ahmad Gammada (Inft.). Balaale. 27 January 2020. Photo, Author.

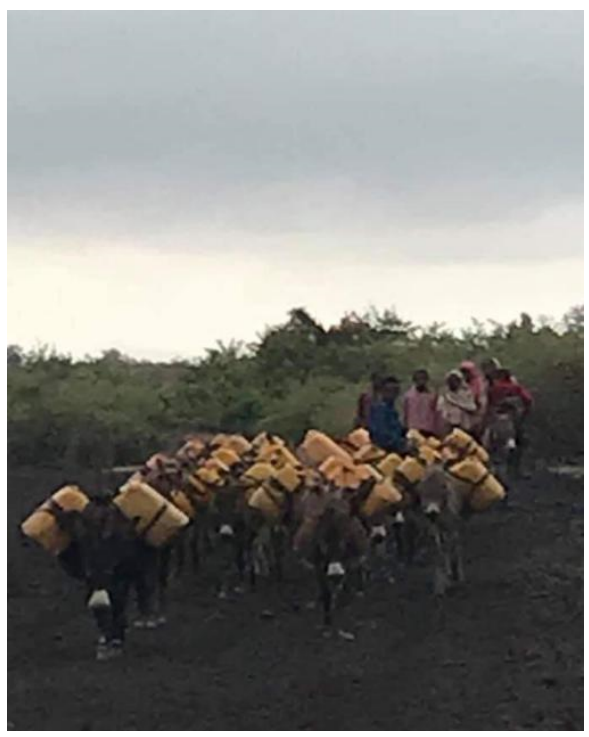

Figure 3. Mount Jaanoo veiled in the cloud, morning, 27 January 2020, southwest of Balaale, and youth with a caravan of water jars from Qooqa (Haroo Roobii). Photo, Author.

Ahmad states in his words next the cultural significance of the ritual celebrated at Mountain Jaanoo in December

\section{[Text 1]:}

... Zaara Jaanoo tu gahe jedhan. Achitti nami (Kirittaannis, Aslaammis, Waaqeffataanis) wal gaha. Waaqa kadhata. Waaqa faarsan; akkas jedhanii seekkaran: Jaaniyyoo

siin godhanna faanoo

leenci hijaabaan (dhoksaan)

jira Jaanoo

oh, Jaaniyyoo, again

here we come to your foot 
Decorated, now and then then,

your lions come home to their den

My informant (Ahmad Gammada) recommended to me two performers named Shubbisee Bobbaasaa Jaatanii and Hussein Galato (in Balaale), who, Ahmad said, are generally known in the area (Balaale) for their familiar talent in the Jaanoo Muudaa performance called seekkara. I met with Shubbise Bobbasa (70) and Hussein Galato (43) in Dheera on 4 March 2020, to collect data about Jaanoo Muuda and other social-ecological systems in the area. Both informants shared to me their lived experience and concern about the religious pressures that weakened the people's cultural practices to maintain an ethical human-nature relationship, to be addressed broadly in the future in a separate study.

\subsubsection{Interview 2: Narrating Haroo Roobii (i)}

(b) What conflicting views do you know of about the human and ecological crisis in Amudde?

Haroo Roobii (Roophii) is a natural lake near Amudde, Doddota District, eastern Arsi. Until it was over-flooded by the man-made Qooqaa Lake in 1960, Haroo Roobii was a sacred site and the sole source of pure water for the people and animals in and around Amudde. Hussein and Shubbise told me that Roobii Lake is called Marxifata on the Balaale side. The informants (Ayya Ubbe, Haj Gammachu, Obbo Fayyo, and others) generally agreed that Haroo Roobii was also another ritual site in the area, after Jaanoo Muudaa near Balaale, for the people to gather from all walks of life, irrespective of region, religion, or gender, and celebrate the Irreecha Thanksgiving ritual ceremony in Birraa, by the end of rainy season in September (Shunkuri 1998).

According to Ayyya Ubbe (Figure 4) of Amudde town, Haroo Roobii is an unforgettable ritual site for the Irreecha Thanksgiving ceremony. At the site, the Oromo women performed songs of rain, fertility, abundance, heroism, love, and light and danced, prayed, and chanted in praise of Waaqa (God) and Ateetee (the goddess of fertility) for the peaceful and quiet rainy season that led toward the shiny Birra season, which is suitable and convenient for all, including livestock and nature in general, on every side of the mountains and rivers and for the people to meet safely and securely.

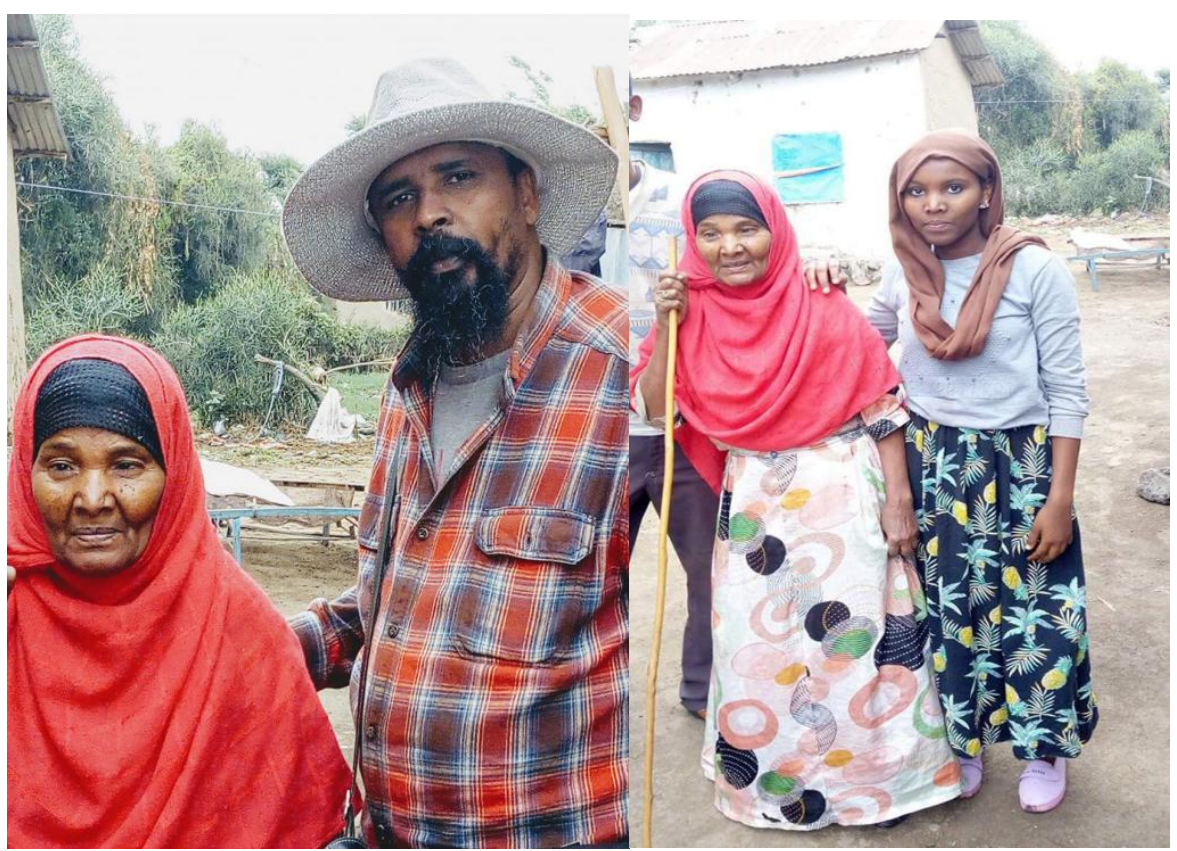

Figure 4. Ayya Ubbe, Amudde. 27 January 2020. Photo, Abadir, an assistant to the Author. 
Sources indicate that the Rift Valley lakes are sources of water and have environmental, cultural, and economic significance (Yeshiemebet 2016; Masresha et al. 2011). Ayya Ubbee (infr.) confirmed to me that until they were prohibited by Sharia, men and women in the area went to the bank of Hara Roobii for Irreecha, a Thanksgiving festival in Birra, September. However, according to Ayya Ubbe, with the coming of a strong Islamic faith to the area, the people were told to drop and forget the indigenous practices labeled "seenaa shamaa", i.e., "filthy tradition", and to stick to Islam and abide by Sharia, as indicated in her words next.

\section{[Text 2]:}

Me: - ... seenaa Haroo Qooqaa kana qorachuudhaaf dhufnee, mee waa nutti himaa

- ... I have come to study the social memory narrative of the Qooqa lake, please tell us some stories about the lake from your experience

Ayya Ubbee (A.U.): ... sheena shamaa dha, dhiisaa 'edhanii, nu dhiisisanii, kunoo salaatat' gorree, irraanfannee, akkam goona egaa? ... Bulee fi lolaalleen nu dhowwe.

- ... we were told to forget our tradition, to drop our folkways as backward, filthy, despicable, and we dropped it gradually, forced to forget it ... what can we do?

After some observable reluctance and indecision, after some struggles to reach her memory pool, Ayya Ubbee performed some ritual songs of Irreecha thanksgiving that she once did with other young married women close to nature at the bank of Haroo Roobii, a small natural lake later over-flooded by the Qooqa dam.

[Text 3]:

irreessaan sii dhufa

yaa malkaa, nagee nagee

irreessaan sii dhufa

yaa malkaa, abeet abeet

we come to your bank

with a ritual grass, oh, sacred lake

we come with a ritual grass

oh, sacred lake, oh, sacred lake

In the context of a religious group where she belonged, which is a Muslim group, my informant hesitantly shared with me a few pieces of information from her scant memory and confessed that she forgot the songs and stories about the sacred sites over-flooded by the man-made lake since her group was told to drop the "filthy backward tradition", as it were, and to abide by Sharia. In this respect, I share James Fentress' and Chris Wickham's (Fentress and Wickham 1992) view that "the sorts of memories one shares with others are those which are relevant to them, in the context of a social group of a particular kind" (p. x). Social memory as a source of knowledge provides us with material for conscious reflection, and the social memory researcher "must situate groups (and group members) in relation to their own traditions, asking how they interpret their own 'ghosts', and how they use them as a source of knowledge" (p. 26). One remembers a memory of an event through performance, that is, through repetition, and Della Pollock (2005) rightly argues that.

At its most basic level, performance is a repetition. It is a doing again of what was once done, repeating past action in the time of acting. Because the repetition occurs in time, it differs from the original to the extent that any one moment differs from another (p. 11).

Furthermore, in spite of her effort to recite some of those sacred songs at the ritual site back then, Ayya Ubbe could hardly remember, and below are just a few of Ateetee songs she sang. 


\section{[Text 4]:}

A.U: ... coqorsa qabannee, siinqee qabannee, okolee keenya qabannee, gaadii loonii qabannee, gubbaa teenya, Waaqa in kadhanna, harariima Birraa keessa, Masqala, Masqala. Irraanfadehee, qaata "salaatat'" dachaanee kana dhiifnee maal?

Ateetiyyoo loonii ti

karaan kashaan daggaggale

ya fandalalee

Ateetiyyoo loonii ti

heexoo kashaan daggaggale

ya fandalalee

heexoo kashaan daggalee

ya giddii malee

... jedhanii dalagan.

Absooliyyoo nooraa

Ayyolee nooraa

silaa dhufa hin ooltu

si waamanii kottu

silaa dhufa hin ooltu

qophii kiyya kottu

... nan irraanfadhe ... kunoo, Allahuu Akubarii! kanatti jammarre (laughing).

... holding a ritual grass and stick, our milk-gourd, our lactating cow-cord, we lower down to the sacred lake ... pray to Waaqa (God), in Birraa (September), and sing songs of Ateetee, the goddess of fecundity ...

... forced to forget it, to drop it, and turned forcefully to pray "salat" ... what can we do?

oh, Ateetee, Ateetee of the cattle

the road to come to you is so grassy, so bushy

oh, you so proud, so grand, \& majestic

oh, Ateetee, oh, Ateetee

the path to you is so crowded

to come to you to pay homage

oh, one must come one must come

... thus, we used to sing in praise of Ateetee on the bank of Lake Roobii (now Lake Qooga):

oh, goddess, we are here

to greet you to worship you

to call upon you to come

we trust, you never stop coming

down, oh, come to us, our Old Mother,

Ayyolee come to my feast come....

The song above is an Ateetee ritual song of peace and fertility performed by women alone. Leila Qashu confirms that "For Arsi women, Ateetee cannot exist without song. Ateetee songs and the action of singing hold the power that solves problems (Dibaba 2020). Within Arsi culture, Ateetee is the only conflict resolution ritual organized and controlled by women and the only one that is sung" (Qashu 2016, p. 356). My informant (A.U.) stressed in her response to my question about whether people in Amudde stopped performing at 
Haroo Roobii simply because the lake was over-flooded by Qooqa Lake (Figure 5), or also because of the influence of Islam and pollution. She answered that people stopped because of Sharia, pollution, and over-flooding.

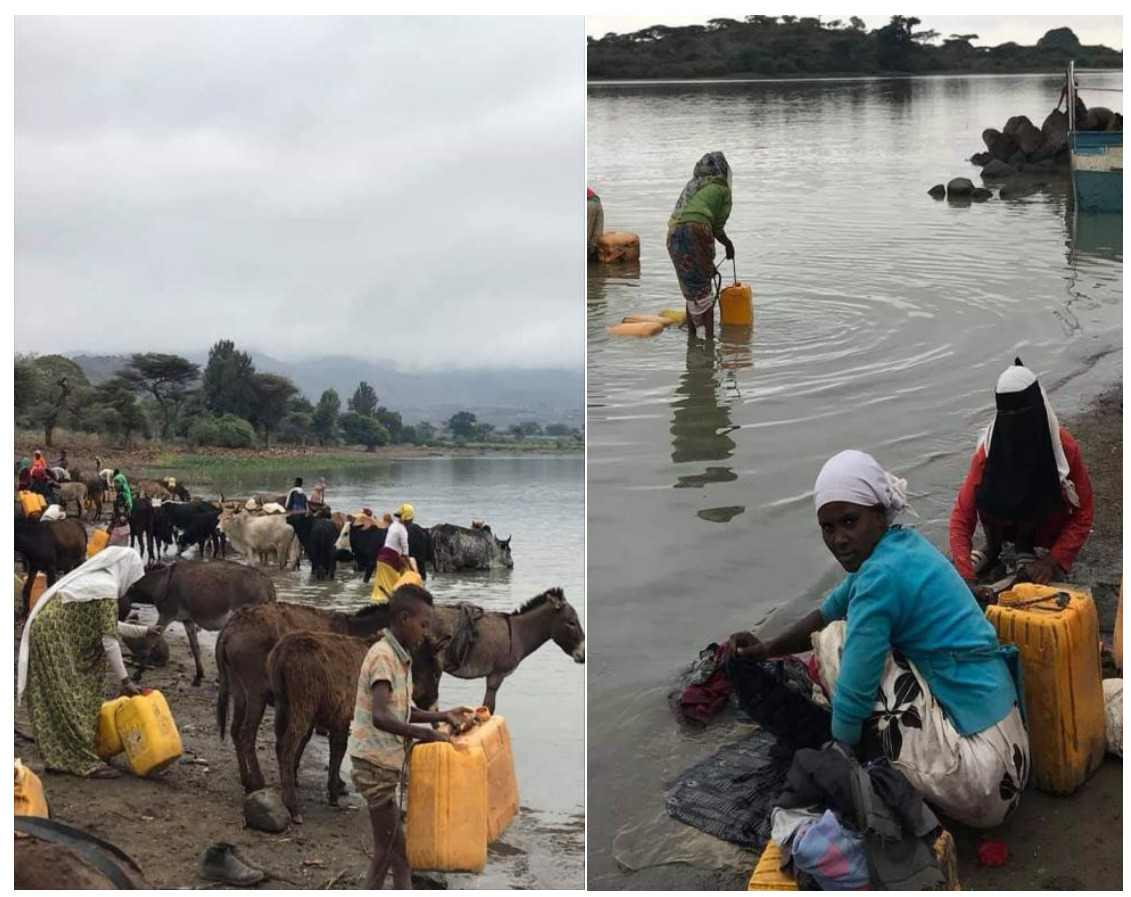

Figure 5. Lake Roobii/Qooqa Lake. Amudde. 27 January 2020. Photo, Author.

\section{[Text 5]:}

Me: Me waan Malkaa Roophii kanaawoo?

A.U.: ... lagni yoo duraa xiqqaa jedhani, akka burqituu wayiitii, hagasii asimmoo guddateeti daariitti as deeme ka roobii tu keessa gala, knf Haroo Roobii jedhan akka duraan jecha dhageenyetti natti fakkaata ... amma wallaalee Ateetee isin jettan, haguma fudhattaniin deemaa (jette, koflaa, garuu saalfachaa fi waakkachaa, afaan ulfinaatiin)

Me: -Haroo Roobiillee malkaan Awash dhufee irra galagalee jennaan dhiiftan moo?

A.U.: Lakkii Sharia. Sharia tu nu harkaa gate.

Me: ... what do you know about Lake Roobii?

A.U.: ... in the past, we heard that it was a small lake made of a well-spring in which hypos lived, hence Haroo Roobii, and recently came to be in its present large size ...

... and now I am done with this Ateetee thing and about the Irreecha thanksgiving festival ... you may be fine with what I told you (she commented very politely and laughingly that she forgot it, also that it may violate Sharia to sing).

Me: ... Then you stopped performing Irreecha on the Roobii Lake because the sacred lake was

over-flooded by Qooqa?

A.U.: ... no! never! the Irreecha thanksgiving festival was banned by Sharia.

Based on the above data, one can observe that the pressure of a non-indigenous religion, i.e., Islam, in the area is felt with remorse to this day, as those good old days, when people enjoyed close observation of and ethical relationship with nature, are long gone as a result of externally induced socio-political and cultural changes. In the past, secret societies of ritual leaders, community elders, rain makers, medicine-men, and, occasionally, the general public, met to worship Waaqa (God) on the bank of the Roobii sacred well-spring and experienced a most relaxing time. The gathering involved Ateetee ritual songs and 
dances for women, whereas, for men, a horse-race accompanied by suunsuma songs and several other performances, which are quite memorable.

The act of remembering is temporally limited, as in A.U.'s narrative. A.U. remembers the lake as a container of facts, as an object of historical loss, and only its blurry image surfaces in her fragmented stories. It makes sense to argue that "unless there is some special association that causes the memory to stick, we may find that we are simply unable to remember ..." (Fentress and Wickham (1992, p. 39)). That is, to remember is to restore the text to its original version and to relocate it back to its social context, which helps the person establish a particular perspective on the past that the oral document represents. Fentress and Wickham (1992) put remembering in two parts, the distinction being between objective fact and its subjective interpretation: an objective part, which is comparatively passive, serves as a container of facts, and situated in a variety of locations, and the subjective part, which is more active and inbuilt, is located only within us, and holds knowledge, information, and feelings, which it experiences and recalls to consciousness (5).

Hence, from what my informants remember about the Oromo ecotheology, a close relationship between man and nature and nature and Waaqa (God) was indispensable (infrs. Ayya Ubbe \& Haj Gammachu). Traditionally, it is common knowledge that "the Oromo ecotheology is mainly concerned with the nature of God, spirits, beliefs, and the relationship between God and humans, and between humans and the natural environment" (Kelbessa 2010, p. 62).

\subsubsection{Interview 3: Narrating Haroo Roobii (ii)}

(c) What are the major causes of Lake Qooqa's water pollution? Where is Haroo Roobii today? What local strategies are used to recount the politics of resources in the area, and what is to be done to envision better humanitarian and ecological situations in your view?

My informant, Haji Gammachu (H.G.) of Amudde (Figure 6), now a Muslim himself, shares Ayya Ubbe's view and remembers with awe the men's horse-race, the suunsuma song and dance, and men's and women's chants and prayers performed on Irreecha thanksgiving day in December on the bank of Haroo Roobii, in the old Qooqa plain of the Siiba Oromo.

\section{[Text 6]}

H.G.: ... Wanna fardaa tu jira ammammoo ... malkaa san bu'uuf, gisee malkaa san irreessa

baasani ... gisee dubartiin magra qabattee, siinqee qabattee malkaaf baatu, nullee garmaamaa oollee, farda qabna, amma, malkaa irreeffachuuf deemna

Me: Malkaa kam?

H.G.: Malkuma Roophii kana.

biifoo biifoo

reeboo reeboo

Caanciyyo biifaa

deebite kaawoon

... jenna.

H.G.: ... there is also a tale of horse-race, of the suunsuma men's song, while women, holding their siinqee (ritual stick), ritual grass sing, pray, and ululate to worship Waaqa on the bank of the sacred lake, Haroo Roobii, now covered by Lake Qooqa.

And we sing a song of Irreecha:

smear, spray (milk)

smear smear 
play, enjoy

oh, Caanciyyoo,

you who smear milk

that time has come back

I asked my informant to recount the story of Haroo Roobii and its surrounding, and he said the land now covered by the lake belonged to the Siiba clan of Jiille Oromo, Tuulma branch, who were washed away in the middle of the night, I was told, when the dam was intentionally opened to break Suuba's fierce resistance to forced eviction from their ancestral land.

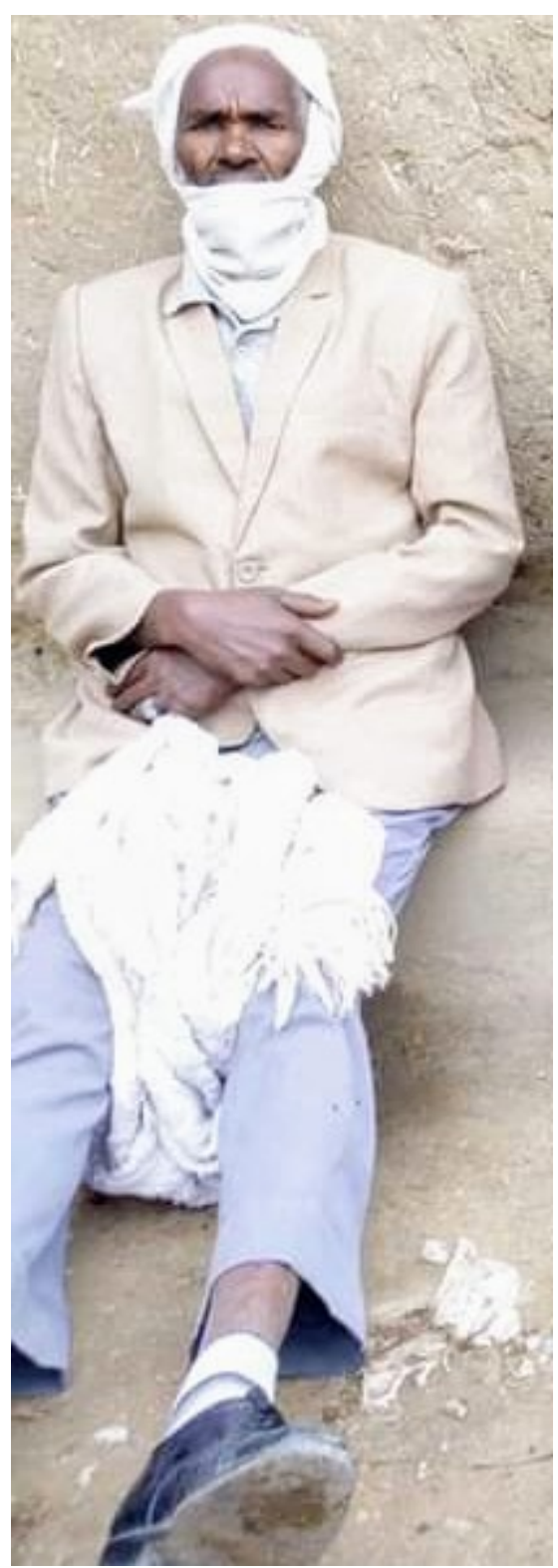

Figure 6. Haji Gammachu Tufaa Guutoo. Amudde. 27 January 2020. Photo Courtesy, Author.

\section{[Text 7]}

H.G: Haroo Roobii, burqaa wayii ture ... dubartiin waraabbatanii qadaadanii biraa galan ... burqituu dha, qadaada qaba ... bakki Qooqaa kun in qotama, yeroo san, shunburaa qotama (bakka amma Qooqa irra ciise kana? Qooqaa kana, eeyyee) ... gubbaa 
Siiba $t^{\prime}$ jiraa ... amma san yoo mangistiin irraa kaasuu jammaruu ... dubartiin wayii, akka abbooti keenya nutti himan, deettuun, qadaada qabaa malkaan, deettuun wayii jarjartee yoo biraa deemtu, achumaan malkaan ganaffale jedhani ... Awash immoo achii as Aanaa Booraa qabatee...

Me: -Eenyutu irra jiraata ture, dur, bakka haroon kun irra ciisu, dur, eenyut' qotata ture? H.G.: -Meedaa achi aanu, Siiba tu qotata ture, gamanaan Arsiin gabaabbinaan ni qabaa ... loon tu dheeda ... bosoqa tu jira, bosoqa kunoo akka shonkooraa kanat' miyaawutu jiraa,...

Me: -Siiba kun Jiille moo, kam?

H.G.: -Jiille, eeyyee ... Oromoo Jiillee . . harma, sodda, waliin dheechifata nami yeroo san ... (waliin dheechifata nami yeroo san?) ... waliin dheechifata eeyyee

Me: -Amma waan suunsumaa, yeroo irreessaa san ... me waan yaadattan ...

H.G.: $\quad$-Suunsuma, nuti yeros dargaggoo dha ... ka qabannu yeroo san nuyi ... fardumaan garmaamuu kana bichaa ... abbooti keenya suunsumanii dhiichisanii, qawwee tokkosan ... ni suunsuman (ni geeraranii? ... abbaa koo! balaan bu'e!) ... nama faarsanii, biyya faarsanii, itti faarsanii ... Giraammash Midhaansoo Nabii jedhanii, baalabbaata yeroo sanii ... yeroo san farda keenya finnee, dubartiin itti elelfattii, birrii 2 birrii 1 akkana in kenninaafii ... baqqaa nuti ulee keenya, farda keenya qabannee, meedaa garmaamaatti dachaana...

Me: -Yoomii kaasee ti bishaan kun kan faalamuu jalqabe, ... bara kami kaaseeti? Buleen kun kemikaalaa?

H.G.: $\quad$-waan isaa beennaa? qaancaa wayii faaqan jedhan ... warshaarraa dhufa ...

- ... mootummaan dhaabatee nurraa dhowwuu dandaha ... daangessuu dandaha, bishaan fidee daariitti nuu baasuu in dandaha ... mootummaat' nuttiraa dhiisi ...

-Bishaan kan dhufee, bara 1959/60 waan taheefi ... buleen tokko Awaash irraan

qodaa afrikaa jedhani ... kun kan kopheeti jedha ... kun kan qaacaa itti faaqan jedha, san itti dhangalaasanii, buleen irraan galagallaan nama hin obaasu ... (Me: Nama hin obaasu) ... nama hin obaasu ... isuma duranuu rakkoo tu ture ... Rabbuma tu nu jiraachise malee ... harreen keessatti dhugee fincaaha ... loon dhugee keessatti fincaaha ... sareelleen in dhuga ... achuma keessatti fincaaha ... garuu namillee isuma dhugnaamiiree ... haa tahuummoo yeroosan nami hin duunee, amma eega buleen kun dhufee amma ... re'een dhume, ..., qotiyyoon du'e ...

H.G.: $\quad$-of Haroo Roobii ... Haroo Roobii was a well spring. Women fetch water from the small lake and close head of the spring ... people plow the Qooqa plain back then .... Siiba of the Jiillee branch lived and plowed there ... and Arsi ... now, when the government started eviction for the dam, we were told, a nursing mother, hurriedly left the well spring open and it flooded the plain in its surrounding until it was over-flooded by the Qooga dam ... and then Awash River through the Booraa district was feeding into the dam ...

Me: -who were residents back then on the Qooqa plain and in its surroundings?

H.G: -Suuba of Jiillee, and Arsi, east side of the lake. And it was rich in a pasture and water... for cattle

Me: -Some Suunsua songs please ... that you performed on the Irreessa festival

H.G.: $\quad$-We were young for suunsuma. We enjoyed the horserace ... our fathers sang suunsuma and

danced ... they sang and praised dignitaries ... landlords ... such as Left-Lieutenant Midhaansoo Nabii and the like... it was huge fun, a joyous time for everone... men and women

Me: -when did the dam start ... and what is bulee about?

H.G.: -the government does not care ... we are helpless ... desperate... 
... the lake was made in 1959/1960. No one knows for sure where the bulee comes from ... some say from a tannery, some say from a cord manufacturing factory ... once they discharge bulee, it is hard to use the water for drinking but we have no choice ... Rabbi (God) protected us so far but we are not safe... in the past, the lake (Qooqa) was not clean either ... livestock drink and urinate and defecate in the lake, and dogs and wild beasts do the same ... however, that was not quite deadly ... with the bulee nowadays, though, animals and people are dying...

\subsubsection{Interview 4: Amina's Personal Story}

(d) What happened to you, Amina, and to your family, and who was responsible?

Qooqa dam (Figure 7), as already discussed in the "Research Setting", is found on the Awash River in the East Shawa Zone, $75 \mathrm{~km}$ southeast of Finfinnee (Addis Ababa), the capital, and south of the main Mojo-Adama road. Galila is one of the lakes around the Qooqa reservoir and located $20 \mathrm{~km}$ south of Mojo town via the Rift Valley road toward Maqi with an area of about 180 square kilometers. The ecosystem around the lake includes the surrounding farmlands, the Awash River, the woodland, and the hot-spring below the dam. The only large trees left around the shores of the lake are qilxuu (figs) as a result of clearing for crop cultivation. Although the main human activity in the area is farming with a special focus on growing horticultural crops and pulses using the alluvial soil, in the area where eviction and pollution became a social problem for over 60 years, land and land resources have been a bone of contention.

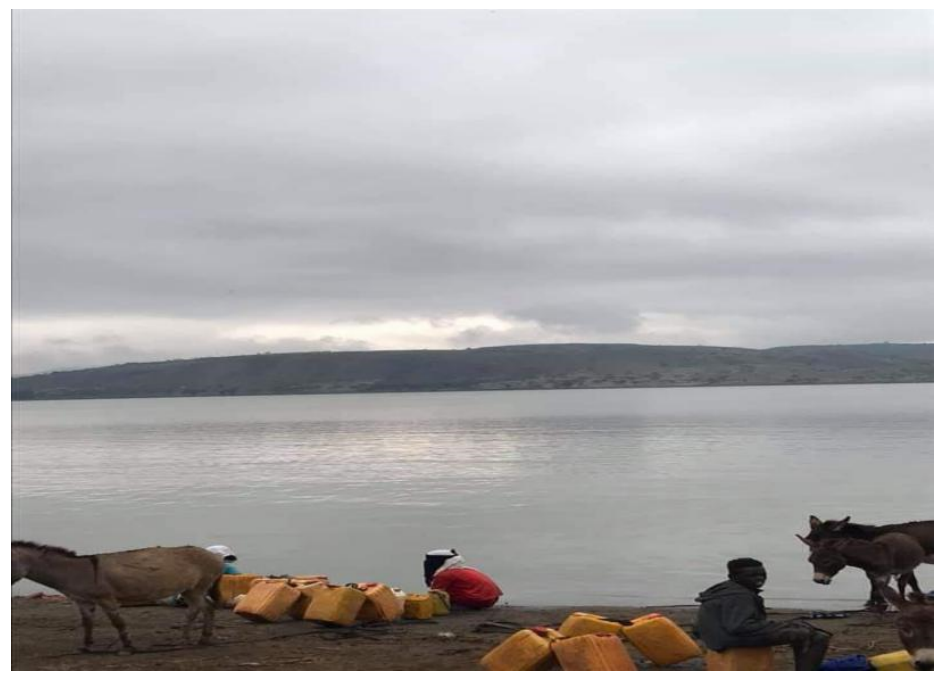

Figure 7. Lake Qooqa. Amudde. 27 January 2020. Photo Courtesy, Author.

Amina is one of the thousands of residents in Amudde who use the Qooqa Lake as the only source of water for drinking, cooking, and washing, as well as for livestock. The February 2009 documentary titled the "Green Lake" by Al Jazeera BBC English Television featured Amina, who lives today shedding tears for her six dearly missed children and her husband, whose deaths were connected to water-related diseases.

The following is a summary of Amina's personal narrative from Amudde, Oromia, which I obtained from the Al Jazeera English program titled People and Power (2009) while I was in exile in USA and later heard the story from Amina in Amudde. Amina confirmed it to me on my visit on 27 January 2020, in Amudde, that the interview (a situational context) was intended primarily to investigate the human and environmental crisis in Amudde village, Qooqa area. Next, with the story I collected from Amina herself (Figure 8) in Amudde town, I relocated Amina's personal experience narrative in a socialmaterial context (social and environmental justices) and in a symbolic-cultural context (social memory/a historical grief of loss). 


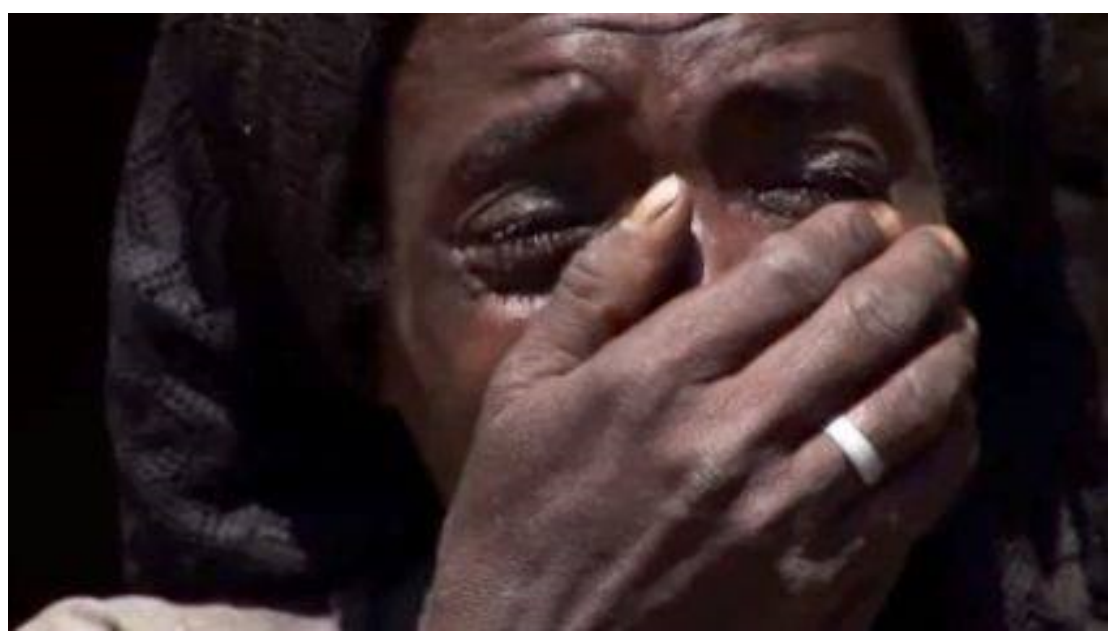

Figure 8. Amina. Courtesy of Aljazeera BBC, "People and Power" program (21 February 2009).

\section{[Text 8]}

I gave birth to nine children. Six of them died: Makida, Hadiri, Tahir, Sultan, Kasim, Kalil. Three survived. My husband also died. I have lost seven members of my family. They were all vomiting and having diarrhea with blood in it. We visited a health center, but we were told the problem was associated with water. I feel sad about my dead children and husband. I wake at night thinking of them, and I now worry if my remaining children will survive. I don't even know if I will survive. Except for God, we have no hope.

Amina is an Oromo mother of nine in Amudde village, near Lake Qooqa. Amina's Story is about water pollution and the dire human and environmental impacts of reckless "development" plans in Ethiopia. I see her personal experience narrative as a symbolic representation of many other unheeded narratives of resentment about social and ecological crisis in the area and elsewhere in Oromia. As Amina's personal experience narrative shows, the pollution of Lake Qooqa in her locality caused over time the consequent human and environmental crises, the tragedy that has become an example of the price of "development without freedom" in the country. Amina's story focuses on the loss of seven members of her family, the historical grief of loss, and a collective memory (shared experience) of the Oromo. This experience of a historical loss is so universal because each story is believed to "echo one or more meta-narratives, local or universal" (Tuval-Mashiach 2014, p. 130).

Upon my visit to Amudde on 27 January 2020, and later, I got a chance to meet with Amina and talked with her about her story of the 2009, her tragic life experience, the loss of her seven family members, and her current life condition. It was quite heartbreaking to hear her account that officials harassed Amina (Figure 9) for telling her accounts of the loss to Al Jazeera BBC reporter in 2009, one year before the national election of 2010. Amina said she was reprimanded and bitterly blamed by the federal and regional officials for telling her stories to Al Jazeera Television about the possible cause of the death of her seven family members, that is, bulee (toxic algae, contamination, or water pollution). Until I left Ethiopia on forced exile in July 2010 to the USA, after repeated persecutions and imprisonment for my writings and speaking to power, I knew that local and regional officials were very cautious about the local people providing information related to the ongoing gross human rights violations in Oromia, which could, no doubt, affect the unfree and unfair national election result. 


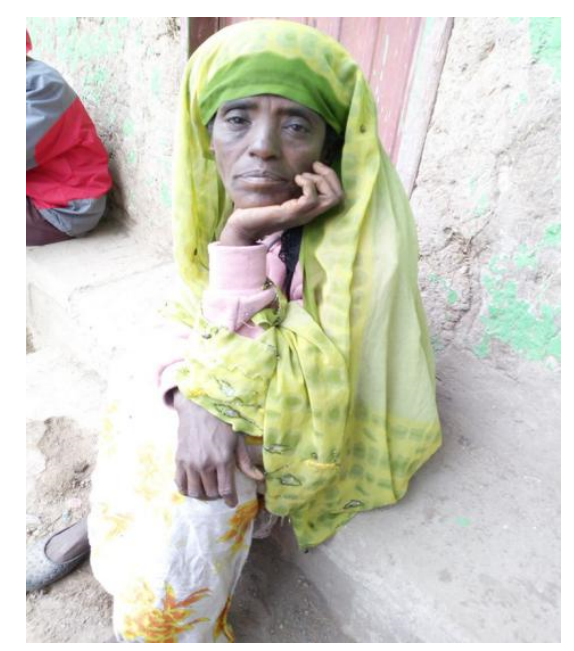

Figure 9. Amina, 27 January 2020, Amudde. Sad, broken, and desperate look. Photo, Author.

Haj Abdu, the then administrator of Amudde, confirmed to me in Amina's presence on 27 January 2020, in Amuude that the incident related to her interview with Al Jazeera BBC was highly politicized. The reason was that the 2010 election was approaching as the documentary was spread worldwide. In effect, the then president of Oromia Regional State, Junadin Saddo, I was told, was pressured to visit the area and promised clean drinking water, electricity, schools, health stations, and roads to calm down the resentful people, none of which were fully materialized; however, after the 2010 national election result was declared, the ruling party called the election fraud a landslide-an overwhelming victory.

\subsubsection{Interview Five: Narrating Lake Qooqa}

(e) What are the major causes of Lake Qooqa water pollution and other challenges to the people and to the environment in which you live? What conflicting views do you know of about the human and ecological crisis in Amudde, and what is to be done?

Lake Qooqa, with an area of 180 square kilometers $\left(69 \mathrm{~m}^{2}\right)$, has a variety of wildlife and birds around the lake. It is reported that the lake contributes to the country's aquaculture with its 625 tones of fish landed each year. Both the lake and reservoir are threatened by increasing sedimentation caused by environmental degradation and the invasive water hyacinth.

I presented to the elders (Figure 10) (a group of four Muslims picked at random) the interview questions next for their personal reflections and open discussions: major causes of Lake Qooqa (and Haroo Roobii) water pollution and other challenges from their perspective, conflicting views and contested narratives they know of about the human and ecological crisis in the area, what local knowledge is worth attending to to alleviate the problem from their lived experience, local strategies used to recount the politics of resources, and what is to be done. 


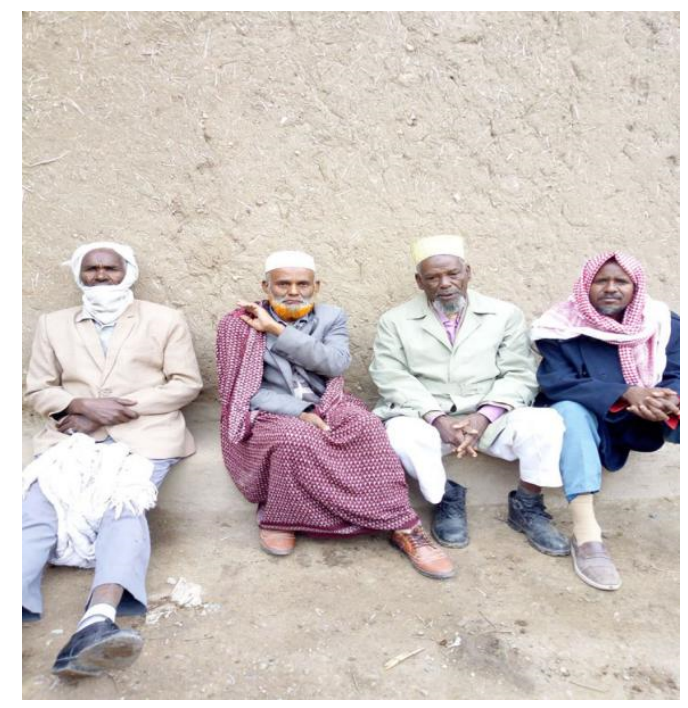

Figure 10. Community elders (Social Group). Amudde, 27 January 2020. Photo, Author.

When I asked Haji Gammachu Tufaa (left) and his group (left to right: Suleiman Jibril, Fayye Jirruu, and Mohammad Qumbii) in Amudde,

(1) Has someone died you have heard of, or animals, related to Lake Qooqa, and what is the cause?

First, Haji Gammachu (H.G.) said the following, to the confirmation of other informants:

\section{[Text 9]}

H.G.: . . e eeyee, likki likkii ... lagarratti nami du'e ... maqaasaan dagadhe ... kanaachi, re'een in dhume, qotiyyoon in dhume, loon in dhumani ... iyyanne, amma aanatti ... bishaan nama fixuu jammaree ... bishaan qulqulluu barbaannaa ... bishaan bulee san nurraa dhaabaa ... ykn baqqaa dhumuu jammarree ... jennee ... eegasii bishaan birkaan tokko jammaree sunuu yawusuma dhufee dhaabatee, akkasumatti ...

H.G.: ... oh, yes. someone died on the lakeside ... I forgot his name ... except that someone ... animals died ... goats, oxen, cattle, ... then we went to the district with complaints for a pure water ... that cattle are dying and people are dying too ... then a pipe line was set up...

My other concern was the availability of a functional local institution to speak for the people, to defend the local interest focusing on their prime concern, and I asked the community elders:

(2) What available local institutions are functional to alleviate the ecological and human crisis?

Some of the community elders in the group had served as members of the local Water Management Committee. Haji Gammachu (H.G.) was one of them and said,

... bishaan boombaa takkaa magaala Goondeerraa dhaabatee ... anuu kunoo an koree bishaaniiti mataa kiyyaa [H.G.] ... haga Goondee deemee iyyadhe, haga aanaa deemnee ... qaamni adda addaa dhufaniima ilaalanii, wanti nuuf godhan hin jiru ... ...

... yoo lafaa qotan bishaan in baha ... bishaan qulqulluu ... in bahaa nuu baasaa jenne, boollayyuu nuu baasuu didanii ... . sanuma dhugaa jirra ... bishaan boollaayyuu immoo kunoo Zuway Duddaarraa kan baasan dhibee godhatee, nama hube ... inniyyuu qoratamuu barbaachisa, bishaan boollaayyuu ...

Me: -amma maal dhuddu isin ree? ...

-laguma san dhugna 
... a pipe line from Goondee to Amudde ... I myself (H.G.) am member of the Water Management Committee ... and then it stopped soon ... now no clean water ... and we placed our complaints to the district officials and no one paid attention to ...

... even boreholes ... drilling wells ... can be risky ... need to be checked in a laboratory by experts for safety ... for example, from Zuway Duddaa, a borehole was drilled and was not safe ... it hurt lives ... even boreholes need care ...

(3) Now, what is your source of drinking water?

Group (G): nothing. just Qooqa, with the bulee (contamitants)

The stories my informants told were their personal life experience of over sixty years in Amudde, and they storied their first-hand accounts of the severity of life-threatening waste discharges into Qooqa Lake.

A study from Debub University and the University of Wales reported in 2001 that the blue-green algae (cyanobacteria), locally called bulee, covers a large area of the lake and causes liver damage, neurotoxicity, and tumor promotion with symptoms of gastrointestinal disorders, fever, and irritation of the skin, ear, eyes, throat, and respiratory tract (Zinabu and Pearce 2003; Yeshiemebet 2016). It has been confirmed in another study that "the most predominant water borne disease, diarrhea, has an estimated annual incidence of 4.6 billion episodes and causes 2.2 million deaths every year" worldwide (Erena 2015, p. 1).

When I asked the group how they could survive and what happened to Amina and her family, they said, if not for Rabbi (Allah), they would have all perished:

(4) What happened to Amina? What caused the death of seven members of her family do you think?

Mohammed Qumbi's view was the following:

\section{[Text 10]}

Me: - ... yeroo Al Jazeera suni eenyunfaa dubbisan yeroo sana?

Mohammed (M.): -Amina jedhamti, namittiin takka ... ishii dubbisanii deeman ... (Aminan garam jiraatti?) ... Buufata Dawweessa Guddaa keessa jiraatti ... buufata baadiyyaa keessa, ganduma kana keessa ... ishii dubbisan akkuma carraa tahanii

Me: -maal taate ishii maal tu irra gahe?

M.: -ishiin hoomtuu irra hin geenyee ... abbaa warraa kiyya faa isatu ajjeese jettee interview goodhattee ... waan akkasii godhattee (... malee abbaan warraa irraa hin duunee?) ... du'e, garuu waan saniin hin duune ... (maaliin du'e?) ... dhimma bishaanii kanaan kan du'ee nami sirriitti beekkamuu, asuma aanuma kana keessa tahee, ganda Loodee Shaarbee jedhama ... .nami sunii, hin beeku ... imala dhufee, hin dhunnelleedhaa, akkuma tasaa tahee, in ajaaya wanti sun ... nami sun qarqara saniiirra deemee ... battalumatti bulee ganama du'ee ... fooliima saniin ... fudhatanii galanii warri awwaallatani

Me: -ka Amina kunimee, ijoollee 6 tu narraa dhume jetti ... abbaan manaallee narraa du'ee jetti ... bishaanuma ... kunoo bulee kanaani jetti ... biyyi maal jedha?

M.: -inni kunii, akkanatti bishaan kanaan, suukanaahee mootummaan, waan san dafee bishaan galchuuf jette malee, dhimmi sun qabatamaan, bishaan kana dhugee nami du'e hin jiru ... horiin in $d u^{\prime}$ a garuu ... harreen, re'een, horiin in $d u^{\prime} a$... knf immoo akka qaama barbaachisutti, haga godinaallee finnee, hagga waggaa darbe (2011 illee) ... fudhatanii deemanii, hoomaa nuuf godhuu hin dandeenye ... yeroo tokko tokko, dhannami isaa waan hin miyoofneef, ... isuma (bishaan boollaa saniiyyuu) shakkisiisaa dha, nuu qoradhaa jennee, Aanaa Zuwaay Duddaa keessatti jechuudha, bishaan akkasii mootummaan baasee ... nama baayyee ija balleessee, kaan harka cabsee, kaan mataa dabsee ti jira ... burqituun lafaa bahu jechuu dha ... keenyumma kana kan dhuunfaatin harka keenyaan qotanne kanayyuu, nuu waraabaa deemaatii, ... nuu qoradhaa deemaatii jennee, ... fudhatuu didee, komii bal'aa irraa in qabna ...

Me: -me ka Amina kanatti nuu deebiyaa ... 
M.: -ka Amina kunii, nuti akkasitti, nama bishaan dhugee du'e hin jiru. garuu komiin sirriitti kahuu, mootummaan deebii waan hin kennineef, anillee akkasuma jechuun dandaya waan akkasii

Me: -yoos kuni kalaqaa ree, ni kalaqamee... uumanii tu Amina faatiin akkas jedhi jedhanii jechisiisanii, Aljazeeran jettuu isin?

M.: -Aminan jedhi namaatiin osoo hin jedhin, fedhiima bishaan qulqulluu akka dhufu qabduuf, laga sanarraallee in fagaatti ... km hedduu deemti, akka keenya kanallee biraa miti, xiqqoo irraa fagaatti bishaanirraa ...

Me: -maaliin dhuman ree maatiin ishee, ijoolleen 6 isheen maqaa dhooftee, ... Kadir, Makida ... jetti, ... nami 7 yoos maaliin du'an ree?

M: -uumamuma Rabbiin du'an malee, bishaaniin hin duune, jarri ... maaliif jennaan, odoo akka ka ishii nami du'ee, naannoo kanarraa nami hunduu du'uu qaba kaa

Me: ... whom did the Al Jazeera TV talk to?

M.: ... they talked to a woman called Amina from the Dawweessa Gudda Center, in the rural area. They met her just by chance.

Me: -why her? What happened to her before that?

M.: ... nothing happened to her. She told the journalist that her husband died of complications of the Qooqa Lake water pollution. ( . . . you mean her husband did not die?) ... he died but not of water pollution. (then what?) ... there has been only one person dead so far of complications related to water pollution ... he was from Loode Shaarbee area, not too far. ... the guy did not drink the water but walked on the lakeside ... said, he died of the ill-smelling contaminated water.

Me: ... so, back to Amina's case. ... she said, she lost her 6 children, including her husband, of the bulee, water conatmitants ... what is your opinion about her case?

M.: ... she told the story of her grave concern about the lack of clean water... she used the unfortunate death of members of her family as a case ... but there have been no human life catastrophe in Amudde so far related to the unclean water ... but animals died ... and we have gone to the Zonal level to place our complaints until just last year ... and no response... we requested to test in the lab. the safety of our borehole waters even ... since borehole water hurt lots of people from Zuway Dudda, and no one paid attention to it ...

Me: ... and of Amina's story?

M.: ... of Amina, no one died because they used the water ... and I myself would tell the same story since the government does not respond promptly or not at all

Me: ... so do you mean that Amina made up the story ... or people used her?

M.: ... no, no one told Amina to tell her story and relate it to the Qooqa water pollution Me: ... so, how did her family perish ... Kedir, Makida, ... and more?

M.: ... they all died a natural death (by Rabbi) ... not by water pollution ... the reason being, if the cause of death in this area were of water pollution, no one could have survived ...

Third, following was Fayyee Jirruu's view:

\section{[Text 11]}

Me: - ... mee abba, isinilleen asuma kana jiraanne jettanii umurii keessan guutuu ... waan kana kan jaarroleen jedhan isin maal jettan? warshaalee balfi hunduu tuujjuba kanatti gad bahaa ... sunimmoo Qooquma kanatti dhufee as gala ... dhibeenimmoo in jirtii ... ha taatuutii nami balfa bishaanii kanaan nurraa du'ellee hin jirtuu jedhu ... isin maal jettan?

Fayyee: - .. nuti wanni jennuu, akka amma qaata jennu, yoo Roophiin adda jiruu, yoo Awash hin makamin dur bishaan qulqulluu dhugaa turree ... haga inni makamee asitti, 
buleen kun, ... eessaa dhufa yoo jennuu, Qaaccaa Faafrikaa kanarraa ... cuunfisaa dhufaa nuun jedhan ... cuunfaan sun gisee kaan bakkuma inni bu'eyyuu hin argan ... yoo bubbeen dhufeetii jedhu ... yoo kaan ititeemati, itittuu tahee, furdaama tahee, wannooma tahee harkifataayyuu ... knf, godaatii in geessa, godaatii horiirra in geessa, horiin gisee mara bokokee du'a, re'een bokottee duuti, harreen bokoktee duuti, san dhuddee ol deebiti ... nummoo Rabbi nuu godhee, minaalbaata, akka Rabbi nuu laaffiseen moojii ... nu garaa qabee kan ajjeese hin agarree, gin immoo bishaan tahu dhugaati hin jirruu, Rabbiif jirra malee, akka bishaaniitii, ittuu deemtanii hin dhiqattanillee, dhuguu dhiisii ... (dhaqee kaasee, achiin dhufaamii?) ... balfa isaa ittuu dhiqachuuf hin taatanii ... kana mootummaani yoo fala itti kaahe malee, nuti waan warshaa saniidha jennee isaanittillee wassanuu hin dandeennuu, ... waan fidemmoo ... Awashuma kana tu fide ... hundarraa haa fiduu, faafrikaa kanarraa haa fiduu, Awashuma kanat' qabee nutti fide (bulee kana isumat' guuree nutti fide) ... isumat' guuree nutti fide

Me: hello ... you said you have been living here all your life and people are saying that all the cotamitants are discharged into Qooga but there is no loss of human life for this reason ... what do you say from your experience?

F: ... look, like everyone said when Haroo Rpphii (Roobii) was a sacred well-spring (lake) on its own and until Lake Qooqa came into existence, we drank a pure water ... once Awash River was made to fill into Qooqa, then the bulee came ... and where it comes from? Some say from the Cord Manufacturing Company (Qaacaa Fafrikaa) ... then its effluents are discharged into the lake... when the wind comes it is gone... floats over the surface of the lake to somewhere else ... and early at the dawn, people go to the lake and fetch clean water... if no wind, its blue-greenish thick matter called bulee floats ... it is dangerous ... it is the Awash River that brought the bulee to us ....

Fourth, Suleyman Jibril confirmed that Lake Qooqa has been the cause for most of the disease people in Amudde suffered.

\section{[Text 12]}

Me: -Waan bishaanii, waan malkaa, haroo kanaa maal beettan? .. Akkamiin dhuddan? Suleyman (S): -waayee bishaanii, akkuma amma isaan jedhan, bulee kana inbeekna ... buleen kun akkanumatti nama miidhaa ... gisee Dargii keecha dhufeyyuu inni ... gisee san baayyee miidhee, yeroo san nami iyyatee, iyyannee, haga ammaattuu in dhufa... haga ammaattilleen isuma dhugna ... rakkina bishaanii akkanatti qabna jechuu dha ... dhibeen warra laga kanarraa baayyeen isaa bishaanuma kanarraayi (maal fayi dhibeen kun..?) ... baasaa, taa'ee, busaa, kanniin kanniin kana, baqqaa ... daawwaa waggaarii (wuhaa-aggaar) jedhan it naqna

Me: -tell us something from your experience about the Qooqa Lake. How do you drink it unclean?

S.: -Like they said (i.e., other informants), the bulee (toxic algae) ... has hurt us for long, starting from the Darg regime (nearly for over 45 years), and we have been complaining, and formally requesting officials to take some action for change but in vain ... and the cause of most of the diseases people suffer here in Amudde and its surroundings, we have been told, come from this polluted water (what are some of the symptoms?) ... vomit, diarrhea, and more ... we use a chemical called "waaggaarii".

The findings above are evidence of the adverse life conditions, cultural and socialecological, of the people in the study area. For years, Qooqa Lake has served over 15,000 people as the only source of drinking water, fishing, and irrigation. However, in the last 50 years, tanneries, flower farms, and various large- and small-scale manufacturing plants of soap, plastic, sugar, and more have sprung up close to the lake without adequate safety plans and waste management regulations to control industrial effluents containing deadly chemicals such as heavy metals and organic pollutants. 


\subsection{Reconsidering Polarized Narrative Trends}

Ethiopia is considered the water tower of east Africa because of its great reserves of surface and groundwater. However, in spite of its available water, the country is unable to provide access to clean water for its citizens. With the reckless growth of urbanization and industrialization inside and around Finfinne, humanity and ecosystems face many "wicked problems" in Ethiopia. Among the powerful tools of a human-rights approach to environmental justice is the folkloric practice of storytelling. Through recounting events (social memory practice) and narrating personal accounts, the data collected, transcribed, and presented about the impacts of environmental assaults on individuals, families, and communities, and the people's culturally oriented adaptive response in the study area are discussed in this section.

Through social memory and personal experience stories, as "through oral history, we can listen to the land speak" (Lee and Newfont 2017). The narratives in songs and stories presented in this study testify to an unmistakable sense of a folkloric pilgrimage that expresses the ecopoetics of a deep-rooted historical grief for human and environmental losses that people in the study area suffer (cf. Estok 2009).

Informants from the study area confirmed in the findings that the dominant political culture that focuses on economic development (without freedom), together with the major religious creeds (Islam and Christianity), desecrated the ritual sites, sacred wells, sacred groves, lakes, rivers, and trees with immeasurable human catastrophe in the name of economic development, a loss which is not compensable. The Oromo in East Arsi, like any other Oromo clans and lineages, regard sacred trees (abdaarii) and sacred groves (qoolloo) as consecrated sites (and totems) "which need respect and protection" (Kelbessa 2010, pp. 75-76).

Workineh Kelbessa underscores in his accounts of the "Oromo Ecotheology" that "the Eastern Arsi Oromo believe that "lafti niitii Waaqaati", i.e., "the Earth is Waaqa's wife", which Workineh doubts is the case (citing sources, Eike Haberland and informants). He adds that, according to Lambert (1983, p. 108), "the Western Matcha Oromo do not consider the Earth as Waaqa's wife. But some informants said that the Earth could be regarded as Waaqa's wife" (Kelbessa, ibid., pp. 69, 70). The latter view holds true, however: I for one come from the Western Macca Oromo of Gomboo Kooraa, Jaarsoo of the Sibu branch, and I grew up chanting and repeating after my parents the following evening prayer and earth song:

... hoo qubaa kee, yaa Waaq!

Dachii Haadha Margoo

Jaartii Jaarsoo

Jaartii Jaarsa qoma dabbasaa,

nuu dhagahi ...

thank you, oh, God!

oh, Dachii, Mother Earth

the Green Handed Deity

the wife of a gray-bearded "old man,"

listen to us...

It is my strong conviction from what I know that the Oromo worldview about humannature relationship and their common knowledge of ecology, that is, alter/native indigenous practices about human-ecology solidarity, is generally interrelated (Bateson [1972] 1987). Hence, the above earth worship and a related narrative Oromo origin such as the mythic "Uume Walaabuu baate", i.e., "Uume (Creation) began at Walaabuu", is an indication of shared Oromo environmental values and a collective lived experience regarding the indispensable human-nature nexus. Gammachu Magarsa (1996) insists that "despite their exposure to other cultures, all the Oromo communities found in East and Northeast Africa 
retain the essential features of their ancient religious and philosophical system of thought" (Kelbessa 2010, p. 25).

According to my informants, in Amuude, like anywhere else in Oromia (for example, Finfinne and its surroundings), forced evictions and development-induced-displacement dislocated the people, particularly the Siiba of Jille branch in the previous Qooqa plain, left their native home abandoned along the Awash River, and desecrated their culturally dominant spaces without trace, including their ritual sites, sacred groves and trees, sacred well-springs, and graves. We have been told that the influence of one of the dominant world religions, Islam, in the study area is another challenge to the people to keep and continue their indigenous practices, cultural expressions and performances, and belief systems (cf. Slovic 1999), which they traditionally used to observe since time immemorial, living and working between Mount Jaanoo and the area now covered by Lake Qooqa (infts., Ayyo Ubbee, Fayyee, Haji Gammachu). The factories and floricultures located over the riverbanks are generally characterized by the increasing human activities with major inflows and the lack of transparent and efficient regulatory institutions, inadequate policy and legal frameworks, and uncontrolled human interactions with the ecosystem, leading into severe ecological and social problems (infts.; Akele T. Seyoum 2011).

My informants stated that Haroo Roophii (Roobii Lake) was separate, attractive, and clean until the Awash River was made to feed into the Qooqa Dam. According to the information obtained from the study area, and from available print sources, the Qooqa Reservoir, which is found within the Rift Valley of Oromia/Ethiopia, is an artificial lake built in 1960 to generate hydroelectric power, of which Addis Ababa is the primary beneficiary, and that the people used the lake as a source of water for drinking, cooking, cleaning, irrigation, and fishing. The reservoir was made by controlling the Awash River watercourse by evicting Siiba of the Jiille Tuulama branch to create the Qooqa dam, which drained the existing bodies of water and over-flooded the smaller natural lake, Haroo Roobii, and, possibly, others. In the creation of the Qooqa Lake, besides the social-ecological and cultural impacts that are not easy to estimate, the severe impacts of the dam on the natural environment were not difficult to assess and to weigh in the balance early in the construction project. The sources also indicate that Qooqa Lake is contaminated with the dirt from Finfinne (the capital), which is discharged into the two Aqaqi Rivers, and the Awash River, and into other tributaries with several factories, horticultures, and floricultures alongside the river banks, which caused the pollution of the lake and the surrounding ecosystem.

\section{Conflicting Worldviews}

Social memory, I argued elsewhere, is a concept used to explore connections between historical events and social identities and helps the researcher to pay attention to both the memory (of a historical grief of loss or of success) and to the social context in which the people debate to agree, disagree, or negotiate conflicting views about their shared past and discuss to create a common ground to meet the needs of the present. The data obtained from the research site indicate nuanced views and opinions about Lake Qooqa and its severe human and ecological impacts related to water pollution, which the people call bulee (green color; hence, another name for Qooqa Lake, the Green Lake). For instance, my informants from Amudde have different views about the fatal death of Amina's seven family members.

Following the Al Jazeera Television Documentary, 2009, based on Amina's story, the Oromo Studies Association (OSA) based in North America joined in a serious debate with Pittards, a UK based P.L.C. investing in leather products in Ethiopia, to address the pollution of Lake Qooqa and referring the problem to the management of the Ethiopia Tannery, later taken over by Pittards. However, Pittards, in its letter to OSA in 2009, denied the accusations, stating that OSA's study of Lake Qooqa's pollution was based on evidence from 2003, whereas Pittards took over the tannery in 2005. Still, its management offered to consider a meeting with OSA to discuss the matter in the future. Four of the 
presentations on one panel of the 2009 Oromo Studies Association took up the issue of Qooqa Lake pollution and the inattentiveness of investors committed to development without environmental sustainability.

Despite the scientific evidence of contamination of the lake (Yeshiemebet 2016; Zinabu and Pearce 2003) and the narratives of grief and loss, the federal and regional authorities and local officials have tried to cover up the immeasurable human and environmental catastrophes and denied people in the area both social and environmental justices. Studies show (Zinabu and Pearce 2003; Yeshiemebet 2016) that there is proven evidence of a high concentration of deadly heavy metals such as mercury, arsenic, chromium, lead, and cadmium above normal levels for clean and drinking freshwater in the lakes along the Rift Valley including Lake Qooqa, chemicals that are said to have negatively affected people's health in the study area (infts.; Yeshiemebet 2016). The World Health Organization (WHO) also found that those heavy metal contaminants are deadly carcinogenic (cancer-causing) chemicals. The same heavy metals were found in the industrial waste discharges from a tannery and in effluents from a textile factory adjacent to the lake (Zinabu and Pearce 2003; www.gadaa.com, accessed on 5 March 2020). The people's dire health and life situation and the environmental impacts of the pollution problem have received no significant efforts so far from governmental officials and NGOs to take appropriate actions by involving the people in decision-making processes about what affects their lives and the environment in which they live and implementing eco-literacy based on the people's indigenous practices used to balance human-ecology solidarity.

Amina's personal narrative shows that as the poor waste-management system in the capital (Addis Ababa) continues, humans and non-humans living on the fringes of the city and around Aqaqi River and Qooqa reservoir, located southeast of the capital, continue to suffer incalculable disaster. Qooqa Lake is a crucial source of water for thousands of people in the Amudde area. To address the sustainability problem caused by water pollution in the area, I posit, it is crucial to integrate the local ecological knowledge and alter/native resilience practices with the scientific knowledge.

\section{Finding Meanings in Social Memory}

It has been the purpose of this project to provide empirical validation for the theory of social memory to improve understanding of the ongoing human and ecological crisis from the people's perspective using a narrative inquiry method. I argued that cultural/social memory refers to the role that culture may play as a resource for connecting the individ$\mathrm{ual} /$ system to the collective shared experience of a significant adversity or risk set in the social context of the whole communities or entire cultural systems. It is not just based on the individual characteristics alone, but also the whole sociocultural environment, which helps the communities to recount adverse conditions and develop a culturally focused resilience adaptation.

Thus, I have made an attempt to show that social memory is an experience of history channeled through the framework of individual life history narratives or personal stories presented in the form of communicative memory, or through cultural memory as a mythical history of origins or events constructed through ceremonial communications and festivals, or through traditional symbolic codifications of past events, or a historical grief of loss recounted through expressive cultures. In line with Maurice Halbwachsian's view, I argue that (externalized) memories originate in a social context, retrieved and changed during interactions among people, and individual remembering or forgetting happens in interaction with the memories of others in practice. That is, a practice-based approach to social memory is an embodied one, a performance of commemorative rituals, and a practice of representing remembrance, an approach which "avoids the dichotomy between oral and script-based cultures" (Bernbeck et al. 2017, p. 18). I have also argued that the act of forgetting becomes actual when distance between people and the object/event to be recalled grows over time, and place as recalling is a "process of evocation indexed by objects"; the acts of recalling "have the character of a commemoration, an act of ethically 
imposed remembering" (Bernbeck et al. 2017, p. 20). In Amudde, as in other oral cultures, I argued that embodiment (i.e., a practice-based approach) is an element of social memory, which is to share the view that "incorporated rather than inscribed memory is essential for a tradition's unbroken survival" (ibid., p. 18).

A further point of this article is that in an attempt to find meanings in memory politics, the politics of resources is used as a metaphor: ethnoecologically speaking, the analysis in this study demonstrated the cultural significance of the sacred lake, Haroo Roobii, and Lake Qooqa as objects of externalized memory, which, metaphorically speaking, have two meanings to the people in the research area. First, as a result of the externally induced and internally motivated socio-cultural changes and religious pressures, the alter/native indigenous practices and lifeways of the people have been dominated by religious and political forces. Second, the fact that people use Qooqa Lake (the Green Lake), which is polluted by contaminants (bulee), has the implication that although they have been facing the human and ecological challenges, forced to use "unclean water" for drinking, washing, cooking, irrigation, and fishing, while they have been dying and suffering throughout the successive regimes, the people are still surviving and sustaining life, despite the unbearable human and environmental conditions.

Through public participation, using social memory and personal experience narrative, future folkloric and other research projects situated in the people's social context can produce positive societal impacts relevant to local ecological knowledge and indigenous practices to enhance group identity, resilience, and a sound human-ecology relationship. This optimism can be subsumed in the people's proverbial metaphor that

bishaaniifi haati xuurii malee xurii hin qaban,

meaning,

There is nothing dirt about water and mother but guilt (once gone).

Funding: The study did not receive any funding from any financial or institutional source. I did the research on my own to fulfill my academic curiosity and to raise awareness as to add to the fund of knowledge.

Institutional Review Board Statement: Ethical review and approval were waived for this study, due to the lack of involvement of any third party to finance or to oversee the ethical and financial aspect of the research. Motivated by the dire impacts of the debilitating human and environmental situation in the study area, I singlehandedly embarked on the project to make some positive impacts by raising awareness.

Informed Consent Statement: Informed consent was obtained from all subjects involved in the study.

Data Availability Statement: No new data were created or analyzed in this study. Data sharing is not applicable to this article.

Conflicts of Interest: The authors declare no conflict of interest.

\section{References}

Ademe, Arega Shumetie, and Molla Alemayehu. 2014. Source and Determinants of Water Pollution in Ethiopia: Distributed Lag Modelling Approach. Intellectual Property Rights 2: 1-6. [CrossRef]

Barrett, Margaret S., and Sandra L. Stauffer. 2006. "Embodied Narrative Inquiry: A Methodoloy of Connection" in Editorial: Narrative Soundings. Crawley: Callaway Centre.

Bateson, Gregory. 1987. Steps to an Ecology of Mind. Northvale: Jason Aronson Inc. First published 1972.

Ben-Amos, Dan, and Liliane Weissberg, eds. 1999. Cultural Memory and the Construction of Identity. Detroit: Wayne State U Press.

Berkes, Fikret. 1999. Sacred Ecology. Philadelphia: Taylor \& Francis.

Bernbeck, Reinhard, Kerstin P. Hofmann, and Ulrike Sommer, eds. 2017. Mapping Memory, Space and Conflict. In Between Memory Sites and Memory Networks. New Archaeological and Historical Perspectives. Berlin Studies of the Ancient World. Berlin: Edition Topoi.

Bradshaw, Bruce. 2002. Change across Cultures: A Narrative Approach to Social Transformation. Grand Rapids: Baker Academic, pp. 1-264. Casey, Edward S. 2010. Between Geography and Philosophy: What Does It Mean to Be in the Place-World? Annals of the Association of American Geographers. 91: 683-93. First published 1996. [CrossRef] 
Central Statistical Agency (CSA) Statistical Report. 2010. Addis Ababa: National Statistics Abstract. Section B. Available online: www.csa.gov.et (accessed on 20 February 2021).

Chamberlin, J. Edward. 2003. If This Is Your Land, Where Are Your Stories? Toronto: Vintage Canada.

Connelly, Michael F., and Jean D. Clandinin. 1990. Stories of Experience and Narrative Inquiry. Educational Researcher 19: 2-14. [CrossRef]

Cox, Paul Alan, and Thomas Elmqvist. 1997. Ecocolonialism and Indigenous-Controlled Rainforest Preserves in Samoa. Ambio 26: 84-89.

Degefu, Fasil, Aschalew Lakew, Yared Tigabu, and Kibru Teshome. 2013. The water quality degradation of Upper Awash River, Ethiopia. Ethiopian Journal of Environmental Studies and Management 6: 58-66. [CrossRef]

Degefu, Fasil, Kibru Teshome, Gashaw Tesfaye, Tefera Fikadu, and Aschalew Lakew. 2011a. Some limnological aspects of Koka reservoir, a shallow tropical artificial lake, Ethiopia. J. Recent Trends Biosci. 1: 94-100.

Degefu, Fasil, Seyoum Mengistu, and Michael Schagerl. 2011b. Influence of Fish Cage Farming on Water Quality and Plankton in Fish Ponds: A Case Study in the Rift Valley and North Shoa Reservoirs, Ethiopia. Aquaculture 316: 129-35. [CrossRef]

Dibaba, Assefa Tefera. 2018. Oromo Social Resentment: Reinvisioning Resentment Theory, an African Perspective. Africology, The Journal of Pan-African Studies 11: 96-122.

Dibaba, Assefa Tefera. 2020. Oromo Orature: An Ecopoetic Approach, Theory and Practice (Oromia/Ethiopia, Northeast Africa). Humanities 9: 28. [CrossRef]

Erena, Gurmesa Oljira. 2015. Investigations of Drinking Water Quality from Source to Point of Distribution: The Case of Gimbi Town. Master's thesis, Addis Ababa University, Addis Ababa, Ethiopia.

Estok, Simon C. 2009. Discourses of Nation, National Ecopoetics, and Ecocriticism in the face of the US: Canada and Korea as Case Studies. Comparative American Studies 7: 85-97.

Fentress, James, and Chris Wickham. 1992. Social Memory. Oxford: Blackwell Publishers.

Ferezer Eshetu, Tegegn. 2012. Physico-Chemical Pollution Pattern in Akaki River Basin, Addis Ababa, Ethiopia. Master's thesis, Stockholm University, Stockholm, Sweden.

Gedicks, Al. 1993. The New Resource Wars: Native and Environmental Struggles against Multinational Corporations. Boston: South End Press.

Gumo, Sussy, Simon Omare, Evans Raballah, and Collins Ouma. 2012. Communicating African Spirituality through Ecology: Challenges and Prospects for the 21st Century. Religions 3: 523-43. [CrossRef]

Hardin, Garrett. 1968. The Tragedy of the Commons. Science 162: 1243-48. [PubMed]

Harris, William Cornwallis. 1884. The Highlands of Ethiopia. 3 vols, London: Longman, Brown, Green, and Longman.

Hassen, Mohammed. 1992. The Oromo of Ethiopia: A History, 1570-1860. New York: Cambridge University Press, pp. xviii, 253.

Hufford, Mary. 1995. Working in the Cracks: Public Space, Ecological Crisis, and the Folklorist. Journal of Folklore Research 36: $157-67$.

Ingold, Timothy. 2003. Three in one: How an ecological approach can obviate the distinctions between body, mind and culture. In Imagining Nature: Practices of Cosmology and Identity. Edited by Andreas Roepstorff and Nils Bubandt. Aarhus: Aarhus University Press, pp. 40-55.

Jackson, Terence. 2002. The Management of People across Cultures: Valuing People Differently. Human Resource Management 41: 455-75. [CrossRef]

Jalata, Asafa. 2012. Gadaa (Oromo Democracy): An Example of Classical African Civilization. Journal of Pan African Studies 5: 1.

Johnson, Leslie Main. 2010. Trail of Story: Travelers Path. Edmonton: Atabasca University Press.

Josselson, Ruthellen. 2006. Narrative Research and the Challenge of Accumulating Knowledge. Narrative Inquiry 16: 3-10. [CrossRef]

Kelbessa, Workineh. 2010. Indigenous and Modeen Environmenntal Ethics: A Study of the Indigenous Oromo Environmenntal Ethics and Modeen Issuess of Environment and Development. In Ethiopian Philosophical Studies, I. Cultural Heritage and Contemporary Change Series. II, Africa. Edited by George F. McLean. Washington, DC: Council for Research in Values and Philosophy, vol. 13.

Kim, Jeong-Hee. 2016. Understanding Narrative Inquiry: The Crafting and Analysis of Stories as Research. Thousand Oaks: SAGE Publishing, pp. 1-368.

Kottak, Conrad P. 1999. The New Ecological Anthropology. American Anthropologist 10: 23-35. [CrossRef]

Krasny, Marianne E., and Keith G. Tidball. 2015. Civic Ecology: Adaptation and Transformation from the Ground Up. Cambridge: MIT Press Scholarship Online.

Lambert, Bartels. 1983. Oromo Religion: Myths and Rites of the Western Oromo of Ethiopia: An Attempt to Understand. In Collectanea Instituti Anthropos. Berlin: Dietrich Reimer Verlag.

Lee, Debbie, and Kathryn Newfont. 2017. The Land Speaks: New Voices at the Intersection of Oral and Environmental History. New York: Oxford University Press.

Lodhi, Abdulaziz Y. 1993. The Language Situation in Africa Today. Nordic Journal of African Studies 2: 79-86.

Luling, Virginia. 1965. Government and Social Control among Some Peoples of the Horn of Africa. Master's thesis, University of London, London, UK.

Magarsa, Gammachu. 1996. Oromumma. Tradition, Consciousness, and Identity. In Being and Becoming Oromo: Historical and Anthropological Enquiries. Edited by Paul Trevor William Baxter, Jan Hultin and Alessandro Truilzi. Upssala: NAI, pp. $92-102$. 
Masresha, Alemayehu E., Lindis Skipperud, Bjørn Olav Rosseland, G. M. Zinabu, Sondre Meland, Hans-Christian Teien, and Brit Salbu. 2011. Speciation of selected trace elements in three ethiopian rift valley lakes (Koka, Ziway, and Awassa) and their Major Inflows. Science of the Total Environment 409: 3955-70. [CrossRef]

Mawere, Munyaradzi. 2013. Traditional Environment Conservation Strategies in Pre-Colonial Africa: Lessons from Zimbabwe. Afro Asian Journal of Social Sciences 4: 1-23.

McAlpine, Lynn. 2016. Why Might You Use Narrative Methodology? A Story about Narrative. Estonian Journal of Education 4: 32-57. [CrossRef]

Mitchell, Matthew C., and Margaret Egudo. 2003. A Review of Narrative Methodology. Edinburgh: DSTO Systems Sciences Laboratory, pp. 1-39.

Mowo, Jeremias G., Zenebe Adimassu, Delia Catacutan, Joseph Tanui, Kenneth Masuki, and Charles Lyamchai. 2011. The Importance of Local Traditional Institutions in the Management of Natural Resources in the Highlands of Eastern Africa. Working Paper No 134. Nairobi: World Agroforestry Centre.

Norris, Fran H., Susan P. Stevens, Betty Pfefferbaum, Karen F. Wyche, and Rose L. Pfefferbaum. 2008. Community Resilience as a Metaphor, Theory, Set of Capacities, and Strategy for Disaster Readiness. American Journal of Community Psychology 41: 127-50. [CrossRef]

Oba-Smidt, Chikage. 2016. The Oral Chronicle of the Borana: Modes of Construction and Preservation of History among People without Writing. New York: Palgrave Macmillan.

Oring, Elliott. 1986. Folk Groups and Folklore Genres: An Introduction. Logan: Utah State University Press, pp. 1-274.

People and Power: The Price of Development. 2009. Dowa: Aljazeera BBC Program, September.

Perrow, Martin R., Adrian J. Jowitt, Julia H. Stansfield, and Geoff L. Phillips. 1999. The Practical Importance of the Interactions between Fish, Zooplankton and Macrophytes in Shallow Lake Restoration. Hydrobiologia 395: 199-210. [CrossRef]

Pollock, Della, ed. 2005. Remembering. New York: Palgrave Macmillan.

Qashu, Leila. 2016. Toward an Understanding of Justice, Belief, and Women's Rights: Ateetee, an Arsi Orono Women's Sung Dispute Resolution Process in Ethiopia. Ph.D. thesis, Memorial University of Newfoundland, St. John's, NL, Canada.

Rappaport, Roy A. 1971. Nature, Culture and Ecological Anthropology. In Man, Culture and Society. Edited by H. Shapiro. New York: Oxford University Press, pp. 237-68.

Ruiz-Mallén, Isabel, Christoph Schunko, Esteve Corbera, Matthias Rös, and Victoria Reyes-García. 2012. Applied research in ethnoecology: Fieldwork experiences. AIBR: Revista De Antropología Iberoamericana 7: 9-30. [CrossRef]

Sandelowski, Margarete. 1991. Telling stories: Narrative approaches in qualitative research. The Journal of Nursing Scholarship 23 161-66. [CrossRef] [PubMed]

Seyoum, Akele T. 2011. The Practice and Challenges of Lake Management in Ethiopia: The Case of Lake Koka. Second Cycle, A2E. Uppsala: SLU, Deptpartment of Urban \& Rural Development.

Sheridan, Michael J. 2008. The Ecology of Fencing. Africa 78: 153-56. [CrossRef]

Shunkuri, Admasu. 1998. Irreecha Oromo Tradition in Thanksgiving: Its Assimilation in Ethiopia. Ethiopian Review 8: 42.

Slovic, Scott. 1999. Giving Expression to Nature: Voices of Environmental Literature. Environment 41: 6-32. [CrossRef]

Sommer, Ulrike. 2017. The Appropriation or the Destruction of Memory? Bell Beaker 'Re-Use' of Older Sites. In Between Memory Sites and Memory Networks: New Archaeological and Historical Perspectives. Edited by Ulrike Sommer, Reinhard Bernbeck and Kerstin P. Hofmann. Berlin: Topoi, pp. 33-70.

Todorova, Maria. 2004. Balkan Identities: Nation and Memory. Budapest: Library of the Central European University.

Tuval-Mashiach, Rivca. 2014. Life-Stories in Context. Narrative Works: Issues, Investigations, and Interventions 4: 125-45.

Vasseur, Liette, and Mikes Jones. 2015. Adaptation and Resilience in the Face of Climate Change: Protecting the Conditions of Emergence through Good Governance. Brief for GSDR, (IUCN, Climate Change Adaptation Group Leader/Brock University) and (IUCN, Resilience Group Leader/Swedish Biodiversity Centre). Available online: https://sustainabledevelopment.un.org/content/ documents / 6579124-Vasseur-Adaptation \%20and\%20resilience \%20in \%20the \%20face \%20of \%20climate $\% 20$ change.pdf (accessed on 20 August 2020).

Yeshiemebet, Major. 2016. Plankton Community Structure and Interactions in a Cyanobacteria-Dominated Tropical Reservoir (Koka, Ethiopia). Ph.D. dissertation, School of Graduate Program of the Addis Ababa University, Addis Ababa, Ethiopia.

Zinabu, Gebre-Mariam, and Nicholas J. G. Pearce. 2003. Concentrations of Heavy Metals and Related Trace Elements in Some Ethiopian Rift Valley Lakes and Their Inflows. Hydrobiologia 429: 171-78. [CrossRef] 